\title{
Motions for Lead Plaintiff in Securities Class Actions
}

\author{
Stephen J. Choi ${ }^{*}$ \\ New York University \\ Draft \#4: February 2008
}

\begin{abstract}
Using a dataset of securities class actions filed from 2003 to 2005, this paper assesses the effect of the lead plaintiff presumption enacted as part of the Private Securities Litigation Reform Act of 1995 (PSLRA) on agency costs between lead counsel for the class and class members. Examining the pre-trial motions for lead plaintiff for each class action, the paper reports evidence that plaintiffs' attorneys retain significant control over the selection of lead plaintiff, cutting side deals to determine the selection of lead plaintiff and thereby lead counsel. Using proxies for where plaintiffs' attorneys have relatively greater influence over the selected lead plaintiff, the paper reports that plaintiffs' attorneys with greater power are able to negotiate higher attorneys' fees as a percentage of the recovery and work fewer hours.
\end{abstract}

Keywords: Securities litigation, lead plaintiffs, class actions.

\footnotetext{
*Email comments to stephen.choi@nyu.edu. Thanks for helpful comments and suggestions from Michael Klausner, Un Kyung Park, and the participants of the University of Michigan Law and Economics Workshop, and the University of Chicago Law and Economics Workshop.
} 


\section{Introduction}

Congress enacted the Private Securities Litigation Reform Act of 1995 (PSLRA) to combat the perceived fear of frivolous litigation in securities fraud class actions and to shift control over class actions away from plaintiffs' attorney firms toward class members. The legislative history behind the PSLRA indicated a concern for "the manipulation by class action lawyers of the clients whom they purportedly represent"- an agency cost problem between the attorneys and the class. ${ }^{1}$ Among other provisions, the PSLRA imposed a presumption that courts will appoint as lead plaintiff the class member making a motion for lead plaintiff with the largest financial interest in the relief from the litigation. ${ }^{2}$ Congress hoped that institutional investors would exert control over the plaintiffs' attorneys, thereby reducing attorney agency costs.

This paper examines how courts after the enactment of the PSLRA implemented the lead plaintiff presumption in selecting among competing movants for lead plaintiff status and how attorney agency costs vary based on the composition and selection of the lead plaintiff. Lead plaintiffs selected pursuant to the PSLRA vary in the number of member investors, the presence of institutional and individual members, the losses suffered by the members, and how frequently the members are participants in securities litigation. Lead plaintiffs also vary in how they are selected. Some lead plaintiffs are selected out of a competitive process with other potential lead plaintiffs. Other lead plaintiffs are aggregated into groups from previously competing motions; still other lead plaintiffs are selected after competing motions withdraw voluntarily.

Using a dataset of securities class actions filed from 2003 to 2005 and all pre-trial motions in these class actions for lead plaintiff status, this is the first paper that systematically examines the pre-trial motions for lead plaintiff and, as a result, provides unique insight into the

\footnotetext{
${ }^{1}$ See H.R. Rep. No. 369, at 31 (1995), reprinted in 1996 U.S.C.C.A.N. 730, 1103.

2 See Section 21D, Securities Exchange Act of 1934.
} 
operation and effectiveness of the PSLRA's lead plaintiff presumption in reducing agency costs. This paper does not directly compare the effectiveness of lead plaintiffs prior to and after the enactment of the PSLRA. Instead, the paper focuses on the effectiveness of different types of lead plaintiffs selected under the PSLRA regime in controlling attorney agency costs.

To measure the level of attorney agency costs, the paper focuses on two areas where the incentives of the class and those of the attorneys potentially deviate: the requested attorney fee award negotiated between the attorneys and the lead plaintiff and the number of attorney hours worked. Plaintiffs' attorneys in securities class actions are compensated as a percentage of the recovery and not directly based on the number of hours worked—leading plaintiffs' attorneys to have lower incentives to exert effort compared with the preferences of the class.

The paper reports evidence that characteristics of the selected lead plaintiff-including the losses suffered by the lead plaintiff, the presence of institutional investors, and how frequently the lead plaintiff makes motions for lead plaintiff status-correlates significantly with attorney agency costs. The paper also reports that the selection process for lead plaintiffsincluding the level of competition and whether previously competing motions for lead plaintiff aggregate to form a joint lead plaintiff-correlates significantly with agency costs. Greater competition may give judges a greater choice among which to select the best lead plaintiff; greater competition may also put pressure on plaintiffs' attorneys to strike more favorable attorney fee agreements with their potential lead plaintiff investor-clients. Courts often approve aggregating groups of previously competing motions, justifying the aggregation as a means of installing lead plaintiffs who jointly have the resources and expertise to best represent the interests of the class. Despite this rationale, the paper reports that aggregation does not always improve agency costs, particularly when non-institutional investors are combined. 
Understanding the impact of the PSLRA's lead plaintiff presumption has important legal implications. Courts have pointed to the PSLRA's focus on installing a strong lead plaintiff as justification for reducing the level of court review of attorney fees in securities class action settlements. In In re Cendant Corporation Securities Litigation, the Third Circuit wrote:

As a preliminary matter, the PSLRA sets out a detailed procedure for choosing lead plaintiffs, the whole point of this process being to locate a lead plaintiff that will be an effective agent for the class.... Our jurisprudence must take account of that change.... We therefore believe that, under the PSLRA, courts should accord a presumption of reasonableness to any fee request submitted pursuant to a retainer agreement that was entered into between a properly-selected lead plaintiff and a properly-selected lead counsel. ${ }^{3}$

If the lead plaintiff does not act as a strong check against attorney agency costs, courts should not follow the position taken in Cendant but instead take a more aggressive stance in reviewing attorney fees and other attorney actions on behalf of the class (including the decision to settle).

Section 2 discusses the literature assessing the PSLRA's lead plaintiff presumption. Section 3 describes the dataset used in the paper's tests. Section 4 examines the variation in the composition of lead plaintiffs and how lead plaintiffs are selected in the dataset and sets forth the paper's hypotheses. Section 5 reports the paper's tests of the determinants of attorney agency costs, focusing in particular on the requested attorney fees and attorney hours worked.

\section{Prior Literature}

In securities class actions, the class faces an agency problem with the lead class counsel. The plaintiffs' attorney may act more risk averse than the investors in the class to the extent the plaintiffs' attorney has invested significant resources in the litigation and is less diversified than the class of investors with respect to the outcome of the litigation (Coffee, 1983). In addition,

\footnotetext{
${ }^{3}$ In re Cendant Corporation Securities Litigation, 264 F.3d 201 (3rd Circuit, 2001).
} 
while the plaintiffs' attorney typically bears the entire cost of the litigation, it receives only a fraction of any recovery or settlement in the form of contingency fees. Plaintiffs' attorneys will thus have an incentive to work less vigorously than optimal from the perspective of the classfor example, settling a meritorious claim early for less than the class as a whole would want to save the plaintiffs' attorneys the expense of continued pursuit of the litigation. On the other hand, plaintiffs' attorneys may have too great incentives to pursue litigation. Plaintiffs' attorneys may engage in frivolous law suits, filing suit even when the expected return from litigating to trial judgment is negative in the hopes of a settlement prior to judgment. ${ }^{4}$

Weiss and Beckerman (1995) first proposed the view that institutional investors, if placed in the lead plaintiff role, would act as effective monitors of plaintiffs' attorney actions in securities class action litigation. Reducing agency costs would not only benefit class members but also reduce the incidence of frivolous litigation. ${ }^{5}$ Congress adopted the Weiss and Beckerman view in enacting the PSLRA's lead plaintiff presumption.

Earlier studies have compared lead plaintiff performance prior to the PSLRA compared with after the Act's enactment in 1995. Choi, Fisch and Pritchard (2005) report that public pension fund participation as lead plaintiff increased significantly after the PSLRA's enactment. They also report that the presence of public pension funds correlates with high value settlements. Simmons and Ryan (2005) and Cox and Thomas (2006) also report that institutional lead plaintiffs correlate with increased settlement amounts. Cox, Thomas, and Bai (2008a) similarly

\footnotetext{
${ }^{4}$ Several have written on the possibility of frivolous securities litigation (Alexander, 1990; Bohn and Choi, 1996; Johnson, Nelson \& Pritchard, 2007; Choi, 2007).

${ }^{5}$ Weiss and Beckerman state that: "When courts review proposed class action settlements, they tend to focus almost exclusively on whether the plaintiff class is receiving adequate compensation for the value of its claims. If those claims have little apparent merit or little evidentiary support and plaintiffs' attorneys have succeeded in securing a relatively substantial recovery for the class, courts also tend to reward those attorneys generously. The prospect of such a reward provides plaintiffs' attorneys with the incentive to initiate and pursue weak claims of securities fraud until they extract a settlement offer from defendants." (Weiss and Beckerman, 1995: 2087-88).
} 
report that institutional investor lead plaintiffs, in particular public pension funds and labor unions, are positively related to larger settlement amounts.

Beyond looking at the correlation between different types of lead plaintiffs and settlement outcomes in securities class actions, there exists little research. Cox and Thomas (2006) report in a study of court motion decisions obtained from the Westlaw and Lexis databases that courts generally selected institutional investors over individual movants for lead plaintiff status. Cox and Thomas's sample, however, omits the majority of court motion decisions on the lead plaintiff, encompassing only decisions where an opinion was posted onto Westlaw or Lexis. Moreover, because their dataset consists of court opinions and not the underlying motions, they omit coverage of motions that were withdrawn prior to the court's decision. Perino (2006) examines the relationship of appointed lead plaintiffs and effort, using the total number of district court docket entries for the litigation as a proxy for attorney effort. However, docket entries are only a crude measure of effort. Docket entries may understate effort to the extent some effort is not tracked through docket entries (such as discovery); docket entries may overstate effort to the extent they represent competing motions (such as for lead plaintiff) or events unrelated to attorney effort (such as changes in the presiding judge or magistrate).

Choi, Fisch and Pritchard (2005) examine the relationship of lead plaintiffs and attorney fees. They report that attorney fees, measured as a percentage of recovery, if anything are higher with private institutional lead plaintiffs after the enactment of the PSLRA compared with the prePSLRA period; they also report no significant correlation exists between fees and public pension funds post-enactment once they control for the size of the case. In contrast, Perino (2006) reports that attorney fees granted by a court are lower with public pension lead plaintiffs.

Despite this scarcity of research, determining the effectiveness of the lead plaintiff 
provision is important not only to assess the level of agency costs between lead counsel and the class but also to understand the impact of the PSLRA on frivolous litigation. If outsized attorneys' fees play a role in driving frivolous litigation (e.g., Weiss and Beckerman, 1995) then putting strong lead plaintiffs in place will help reduce the incidence of frivolous litigation.

\section{Dataset Description}

The dataset consists of all securities class actions identified in Stanford's Securities Class Action Clearinghouse database as filed from 2003 to 2005 . I eliminated class actions involving a primary corporate defendant not in a financial services related industry (SICs 6000 to 6999) because of special regulatory regimes that apply to such firms, giving a total of 482 class actions. For each class action, I collected data from PACER, Westlaw, and from the Securities Class Action Clearinghouse on the federal district court docket for each class action and the motions

for lead plaintiff and the ultimate selection of the lead plaintiff and lead counsel. I also collected information on the outcome of the litigation. In the case of settlement, this information included the amount of the settlement, the attorney fee requested, and the number of attorney hours worked in the litigation. Panel A of Table 1 gives summary data.

[Insert Table 1 Here].

\section{Lead Plaintiff Hypotheses}

Not all lead plaintiffs selected pursuant to the PSLRA's lead plaintiff presumption are the same. This section examines variation in the composition of the lead plaintiff and in the selection process for lead plaintiff and sets forth the paper's hypotheses relating lead plaintiff composition and selection with attorney agency costs. 


\subsection{Composition of the Selected Lead Plaintiff}

Table 2 provides summary statistics on the selected lead plaintiff. Most lead plaintiffs consist of more than one investor. I hypothesize that the greater the number of members of the lead plaintiff, the less incentive any single member will have to negotiate with and monitor the actions of the lead counsel (e.g., Heck, 1999). For the paper's tests, I use an indicator variable for whether the lead plaintiff consists of more than 3 members (Many_Lead_Plaintiff).

[Insert Table 2 Here].

Different types of investors serve as lead plaintiff. I define "institutional investor" to include financial institutions, such as insurance companies, pension funds, banks, mutual funds, and hedge funds. An "Institutional Lead Plaintiff" is defined as a lead plaintiff with at least one institutional investor member. I further divide Institutional Lead Plaintiffs into lead plaintiffs comprised solely of institutional investors (All_Institutional; representing 36.7\% of the lead plaintiffs) and lead plaintiffs consisting of a mixture of institutional and non-institutional investors (Mixed_Institutional; representing 19.1\% of the lead plaintiffs). I also examined the importance of specific categories of institutional investors. Public pensions funds (Public_Pension) were part of the selected lead plaintiff $13.4 \%$ of the time; labor union pension funds (Labor_Unions) were part $16.5 \%$ of the time.

A "Non-Institutional Lead Plaintiff" is defined as a lead plaintiff composed of solely individuals as well as non-institutional investor entities. Non-Institutional Lead Plaintiffs account for $44.1 \%$ of the lead plaintiffs in the dataset and consist primarily of individuals. Of the 19 non-institutional investors that made at least 2 motions for lead plaintiff in the dataset, 18 were individuals and only 1 was an entity (see Appendix C). I hypothesize that with greater resources and expertise, Institutional Lead Plaintiffs will act as a greater check on the influence 
of plaintiffs' attorneys. Non-Institutional Lead Plaintiffs, in contrast, typically lack resources and expertise. Moreover, evidence indicates the some degree of corruption existed in the relationship between some individual lead plaintiffs and Milberg Weiss, the largest plaintiffs' attorney firm. In 2006, the Justice Department indicted Milberg Weiss, and senior partners at the firm, including Bill Lerach (who had split away from Milberg Weiss to form Lerach Coughlin) and Melvyn Weiss, for alleged kickbacks to primarily individual lead plaintiffs from 1994 to 2005. Lerach and Weiss eventually pled guilty to the charges in 2007 and 2008 respectively.

Variation also exists in the losses of the selected lead plaintiff. Table 3 reports summary statistics on the losses of the selected lead plaintiffs in the dataset (as represented by the lead plaintiff to the court in its motion for lead plaintiff), ${ }^{6}$ separating the losses for both lead plaintiffs that consist of at least one institutional investor and lead plaintiffs that consist solely of noninstitutional investors. Institutional Lead Plaintiffs suffered mean (median) loses of \$3.9 million (\$374.3 thousand). In contrast, Non-Institutional Lead Plaintiffs suffered mean (median) losses of only $\$ 308.3$ thousand ( $\$ 108.1$ thousand). For both institutional and non-institutional lead plaintiffs, the bottom part of the loss distribution extends to very low dollar amounts in absolute terms. The Non-Institutional Lead Plaintiff with the smallest losses reported losses of only $\$ 61 .^{7}$ The Institutional Lead Plaintiff with the smallest losses reported losses of only $\$ 1,510 .^{8}$

[Insert Table 3 Here].

Negotiating with potential lead counsel and monitoring the activities of lead counsel takes time and effort. Without a correspondingly greater benefit for those acting as lead plaintiff

\footnotetext{
${ }^{6}$ Where the lead plaintiff motion indicated that losses were "at least" a certain reported amount or equivalent language, I used the certain reported amount as the measure of provable losses.

${ }^{7}$ This was not the only extremely low loss. The next three smallest losses for Non-Institutional Lead Plaintiffs were $\$ 800, \$ 1,374$, and $\$ 1,518$.

${ }^{8}$ Other Institutional Lead Plaintiffs also suffered only minor losses. The next three smallest losses for Institutional Lead Plaintiffs were $\$ 5,433, \$ 7,282$, and $\$ 14,039$.
} 
relative to the other class investors, it is unclear how much effort the lead plaintiff will take on behalf of the class. Lead plaintiffs typically receive only their pro rata share from the settlement fund. Cox and Thomas (2006) report from a confidential survey of institutional investors that the cost to an institutional investor of acting as lead plaintiff in an average case is between $\$ 25,000$ and $\$ 100,000$. Even an institutional investor is unlikely to find expenditure of significant effort worthwhile if its potential maximum relief from the litigation is only $\$ 1,510$.

For the paper's tests, I use an indicator variable for whether the lead plaintiff's losses are at the median or lower compared with the group of all lead plaintiffs (LowLoss). Low losses may affect institutional and non-institutional lead plaintiffs differently. I also use an indicator variable for whether an Institutional Lead Plaintiff has median or lower losses for all Institutional Lead Plaintiffs (LowLoss_Inst) and an indicator variable for whether a Non-Institutional Lead Plaintiff has median or lower losses for all Non-Institutional Lead Plaintiffs (LowLoss_NonInst).

Many lead plaintiffs are frequent movants in the dataset. I define Frequent Institutional Movant as an institutional investor that was part of a motion to become lead plaintiff in more than one class action in the dataset. I define a Frequent Non-Institutional Movant as an individual or non-institutional investor entity that was part of a lead plaintiff motion for more than one class action in the dataset. Table 4 reports that of the 1,277 competing motions across all the class actions in the dataset as a whole, 144 (or 11.7\%) were brought by a movant that included a Frequent Institutional Movant. In contrast, only 40 (or 3.3\%) of the motions were brought by a movant that included a Frequent Non-Institutional Movant. Appendix C lists the Frequent Institutional and Non-Institutional Movants in the dataset.

[Insert Table 4 Here]. 
The PSLRA limits the number of times an investor may act as lead plaintiff to no more than 5 securities class actions brought as plaintiff class actions pursuant to the Federal Rules of Civil Procedure during any 3-year period (although no limits exist on the number of times an investor may make a motion for lead plaintiff). Despite the equal application of the limit on frequent lead plaintiffs on all types of investors, Frequent Institutional Movants may have a different effect on attorney agency costs compared with Frequent Non-Institutional Movants. Table 4 reports a comparison of the motions by Frequent Institutional Movants and Frequent Non-Institutional Movants. The majority of motions by Frequent Institutional Movants are selected as lead plaintiff (52.9\%). In contrast, only $28.9 \%$ of Frequent Non-Institutional Movants are selected as lead plaintiff (difference significant at the $5 \%$ level). Frequent Institutional Movants are much more likely to group together with another Frequent Institutional Movant in a single motion for lead plaintiff than Frequent Non-Institutional Movants are with other Frequent Non-Institutional Movants, ${ }^{9}$ indicating that Frequent Institutional Movants communicate with other institutions beyond the context of any single class action. I hypothesize that the greater involvement by Frequent Institutional Movants gives them greater expertise in negotiating with and monitoring plaintiffs' attorneys compared with non-institutional investors.

Frequent Institutional Movants and Frequent Non-Institutional Movants also differ in how often they associate with the same law firm. For each frequent movant, I determined the attorney firm that associated with the movant the most times (termed the "Most Frequent Attorney"). Frequent Institutional Movants associate with their Most Frequent Attorney 81.7\% of the time. In contrast, Frequent Non-Institutional Movants associate with their Most Frequent Attorney $63.2 \%$ of the time (difference significant at the $5 \%$ level). A frequent connection

\footnotetext{
${ }^{9}$ No Frequent Institutional Movant grouped together in the same motion with a Frequent Individual Movant in the dataset.
} 
between investor-movants and attorney firms may give the investors greater knowledge and advantage over the attorney firm. The reverse is also possible - the attorney firm may simply use a willing investor-puppet (or, alternatively, an unknowledgeable investor unable to control the lead counsel) to advance the attorney firm's best interests. I test between these hypotheses, analyzing the impact on attorney agency costs of both institutional investor and non-institutional investor lead plaintiffs that were frequent movants for lead plaintiff.

\subsection{Lead Plaintiff Selection Process}

When making their initial motion for lead plaintiff, class members come already associated with a proposed lead counsel (or, in some cases, multiple co-lead counsels). After the selection of lead plaintiff, there typically is no subsequent contest to determine lead counsel. Instead, courts almost always approve the selection of the lead plaintiff's initially proposed lead counsel. Competition in the selection process for lead plaintiff and lead counsel comes solely at the motion stage for lead plaintiff.

Table 5 reports summary statistics on the number of motions for lead plaintiff. The mean number of competing motions per case was 2.84 motions. On average, courts selected 1.15 motions, indicating that courts allowed competing lead plaintiff movants to aggregate into groups (discussed below). Movants that courts did not select as lead plaintiff either withdrew ahead of the court's decision or were rejected by the court at the time the court selected another movant as lead plaintiff. The distinction between movants that voluntarily withdrew and movants that were rejected is discussed below. Most motions for lead plaintiff included at least one institutional investor (either in an institutional investor-only motion or a mixed motion with both institutional and non-institutional investors). Institutional investors do not always prevail 
over non-institutional investors for appointment as lead plaintiff. Where both institutional and non-institutional investor movants competed for lead plaintiff in the same case, non-institutional investors were appointed over institutional movants in $17.8 \%$ of the cases.

[Insert Table 5 Here].

Where separate investors move to obtain lead plaintiff status, competition may lead to a reduction in attorney agency costs for two reasons. First, competition may force attorneys to strike a more favorable attorney fee arrangement with the prospective lead plaintiff - both because the lead plaintiff may decide otherwise to switch to another attorney and because courts may look more favorably on attorneys that strike such deals. Second, courts faced with more choices for lead plaintiff and lead counsel may have greater leeway to select a better combination of lead plaintiff and lead counsel to act on behalf of the class. I hypothesize that cases with more competing motions will correlate with a lower level of attorney agency costs. For the paper's tests, I use the number of separate competing motions (Number_Separate_Motions) as a measure of the competitive environment for lead plaintiff selection.

Not all filed motions for lead plaintiff make it before a judge for decision on the merits. Instead, movants often voluntarily withdraw their motions ahead of a judge's decision. For example, in 2004, investors filed a securities class action suit against Intermune, Inc. in the Northern District of California. As depicted in Appendix B, four separate movants sought lead plaintiff status. The judge, however, never assessed the relative merits of the four movants. Instead, three of the four movants withdrew their motions. The remaining movant (Lance A. Johnson) was subsequently selected lead plaintiff. The movant's proposed lead counsel, Goodkind Labaton Rudoff \& Sucharow LLP, was then selected as lead counsel. 
Panel A of Table 6 gives summary data on the fraction of cases where at least one competing motion for lead plaintiff withdraws. Panel A also reports the fraction of cases with at least one withdrawal that ended up with no competition for lead plaintiff (Withdraw and No Competition) and the fraction of cases with at least one withdrawal that ended up with at least two competing motions for lead plaintiff (Withdraw and Competition). Note that more than half of the cases with a withdrawal end up with no remaining competing motions.

[Insert Table 6 Here].

Movants may withdraw once they realize that another movant has greater losses and thus will likely enjoy the presumption of lead plaintiff status under Section 21D of the Exchange Act. Plaintiffs' attorney firms that are less frequent participants in securities class actions may lack securities class action-specific expertise to fight with larger plaintiffs' attorney firms and instead choose to withdraw; less frequent participant attorney firms may also have fewer contacts with investors who may potentially act as lead plaintiff, reducing their ability to find a large loss investor to propose as lead plaintiff; less frequent participants attorney firms often are smaller in size compared with more frequent participant firm (collectively, I refer to these as the frequent attorney hypothesis). On the other hand, movants may withdraw due to side deals between the counsel for the withdrawing movant and the counsel of the remaining movants (either to obtain part of the litigation work in the present litigation or in return for the counsel of the nonwithdrawing movant agreeing to withdraw in an unrelated litigation involving both counsel). Those attorneys with greater repeat interaction with other counsel may be more likely to engage in such side deals (the side deal hypothesis).

In the Intermune securities class action, the proposed lead counsels for the three withdrawing motions and the selected motion are each among the most frequent lead counsel in 
the dataset (Schiffrin \& Barroway, Milberg Weiss Bershad Hynes \& Lerach LLP, Cauley Geller Bowman \& Rudman LLP, and Goodkind Labaton Rudoff \& Sucharow LLP) (see list of frequent lead counsel in Appendix D). These attorney firms have a higher degree of repeat interaction with each other than less frequent lead counsel. Moreover, the selected lead plaintiff did not have the largest claimed losses (with losses of $\$ 40,000$ ); instead, one of the withdrawing movants, Gerald Fraschilla and Darlene Fraschilla, had the largest claimed losses $(\$ 57,735)$.

As a test of whether withdrawals occur through side deals, I estimate a logit model for whether a movant that is not selected lead plaintiff withdraws (equal to 1) or is rejected by a judge (equal to 0). Using pre-trial motion-level data and fixed effects for a particular class action, the logit model is:

$$
\begin{aligned}
\operatorname{Prob}\left(\text { Withdraw }_{\mathrm{i}}\right) & =\alpha+\beta_{1_{\mathrm{i}} \mathrm{Mid}_{\text {_Attorney }}+\beta_{2 \mathrm{i}} \text { Bottom_Attorney }_{\mathrm{i}}} \\
+ & \beta_{3 \mathrm{i}} \text { Number_Attorneys }_{\mathrm{i}}+\text { Class Action Effects }+\varepsilon_{\mathrm{i}}
\end{aligned}
$$

If a lack of frequent participation in class actions drives withdrawal (the frequent attorney hypothesis), I expect that less frequent plaintiffs' attorneys firms will withdraw more often than more frequent plaintiffs' attorneys firms (and the relationship between withdrawal and attorney firm frequency will be monotonic). I use attorney firms that were chosen as lead counsel in at least 10 cases (Top_Attorney10) as the category of firms most likely to have sufficient resources to fight a lead plaintiff motion, including not only the very largest attorney firms but a range of firms with significant presence in securities class action litigation such as Goodkind Labaton Rudoff \& Sucharow LLP and Berger \& Montague P.C. Appendix D lists the Top_Attorney10 firms. The model includes two indicator variables to compare the probability of withdrawal against Top_Attorney10 as the base category. Bottom_Attorney is defined as attorneys that were selected as lead counsel 1 or 0 times in the dataset. Mid_Attorney are those attorneys that were 
selected between 2 and 9 times in the dataset. ${ }^{10}$ The model also includes the total number of attorney firms the motion proposes as (co)-lead counsel (Number_Attorneys).

From Model 1 of Panel B of Table 6, note that the coefficient on Bottom_Attorney is positive and significant at the $10 \%$ level. This result is consistent with the hypothesis that firms with less frequent securities class action participation are more likely to withdraw their motion for lead plaintiff. On the other hand, the coefficient on Mid_Attorney is negative and significant at the 5\% level. In contrast to the most frequent attorney firms, the mid-frequency firms are less likely to withdraw their motions, inconsistent with the frequent attorney hypothesis. Instead, this result is consistent with the view that the larger, more frequent participant firms are more likely than mid-frequency firms to withdraw because of side deals with other repeat plaintiffs' attorney firms. Model 2 of Panel B of Table 6 adds control variables for the number of movants in the motion for lead plaintiff (Number_Movants), the fraction of institutional investors among the movants (Institutional_Movant_Fraction), whether at least one of the movants is a Frequent Institutional Movant, and whether at least one of the movants is a Frequent Non-Institutional Movant. Model 2 reports the same qualitative results as Model 1 except that Mid_Attorney is negative and now significant at the $<1 \%$ level. I, nonetheless, lack data on the claimed losses of each movant for lead plaintiff and thus cannot rule out the possibility of omitted error bias.

To the extent side deals are driving withdrawals, I hypothesize that greater numbers of withdrawals correlate with a less competitive environment and increased plaintiffs' attorney strength (and thus greater agency costs). To test this hypothesize, I construct a variable for the number of withdrawn motions in a particular case (Number_Withdraw).

\footnotetext{
${ }^{10}$ Note that for each category of attorneys, I omitted counting the lead counsel firms selected for the particular case in question in determining the frequency an attorney firm was selected lead counsel in the dataset to avoid endogeneity problems.
} 
Despite the lead plaintiff presumption of the PSLRA, judges do not always select the lead plaintiff with the greatest financial interest in the relief from the litigation. Instead, separate, competing lead plaintiffs may combine as a group to seek lead plaintiff status jointly. In 2004, investors filed a securities class action suit against Spear \& Jackson in the Southern District of Florida. As depicted in Appendix B, four separate movants sought lead plaintiff status. Instead of selecting the movant with the largest losses (First Mirage Inc., Profit Concepts Ltd., Generation Capital Assoc., and American Merchant Press Inc.), the judge allowed the combination of three of the four initial movants to form one consolidated lead plaintiff group consisting of 6 members. Rather than have the three groups select one lead counsel, the judge also approved the selection of one counsel from each of the three separate groups to act as colead counsels (Lerach Coughlin Stoia Geller Rudman \& Robbins LLP, Schiffrin \& Barroway LLP, and the Law Offices of Bernard M. Gross PC). This combination of plaintiffs' attorney firms as co-lead counsel is common when competing motions aggregate. The average number of co-lead counsel when a group is not formed from competing motions is 1.35 ; the average number when a group does form is 2.03 (difference significant at the $<1 \%$ level).

Courts justify the aggregation of competing motions for lead plaintiff as beneficial for the welfare of class members. For example, in a securities class action involving Rule 10b-5 fraud allegations against specialist firms on the New York Stock Exchange, a federal district court allowed the aggregation of two separate motions, arguing that aggregation "will help to ensure that adequate resources and experience are available to the prospective class in the prosecution of this action. Employing a co-lead plaintiff structure here will also provide the proposed class with 'the substantial benefits of joint decision-making"' ${ }^{11}$ Despite the arguments in favor of

${ }^{11}$ Pirelli Armstrong Tire Corp. Retiree Medical Benefits Trust v. LaBranche \& Co., Inc., 229 F.R.D. 395, 420 (citing to In re Oxford Health Plans, Inc. Sec. Litig., 182 F.R.D. 42,45 (S.D.N.Y. 1998)) (2004). 
aggregating groups of lead plaintiffs, groups that form at the convenience of the proposed lead counsel often consist of members that have no prior connection with one another (other than being joined together during the litigation as a lead plaintiff group) and may not reduce attorney agency costs. I hypothesize that this is particularly the case for groups of non-institutional investors. In contrast, evidence exists that institutional investors may work effectively together in shareholder-related matters. In a survey of institutional investors, McCahery, Sautner and Starks (2008) report that $59 \%$ of the respondents reported that they would consider coordinating their corrective actions relating to shareholder activism with other investors. To test the effect of aggregating motions for lead plaintiff, I use indicator variables for whether competing motions for lead plaintiffs aggregate into a group with at least one institutional investor (Group_Institution) or solely non-institutional investors (Group_Non-Institution). I hypothesize that groups of institutional investors reduce attorney agency costs while groups of noninstitutional investors will not reduce agency costs.

Given the possibility that movants for lead plaintiff may withdraw due to side deals among plaintiffs' attorneys, I also test the hypothesis that lead plaintiffs that aggregate into groups after all other competing motions have withdrawn voluntarily (and thus represent a side deal among all the plaintiffs attorneys) may not improve agency costs relative to lead plaintiffs that do not form out of an aggregation of competing motions. In contrast, groups that aggregate in the face of continuing competition from other movants for lead plaintiff are less likely to represent merely a side deal in furtherance of the interests of plaintiffs' attorneys and thus may correlate with reduced attorney agency costs. For this test, the paper uses an indicator variable for whether competing motions for lead plaintiffs aggregate without opposition from any other competing movant for lead plaintiff (Group_No_Competition) and an indicator variable for 
whether competing motions aggregate and are selected lead plaintiff jointly while facing at least one competing movant (Group_Competition).

[Insert Table 7 Here].

Table 7 reports the frequency with which initially separate lead plaintiff movants aggregate to form a joint lead plaintiff (Aggregation; 13.9\% of the cases involved an aggregating lead plaintiff). Table 7 reports the fraction of aggregating groups that consisted solely of noninstitutional investors (Group_Non-Institution; 4.8\% of the cases involve an aggregating lead plaintiff with just non-institutional investors). Panel $\mathrm{C}$ also reports that fraction of aggregating groups that resulted in a combined lead plaintiff with at least one institutional investor (Group_Institution; 9.1\% of the cases involve an aggregating lead plaintiff with at least one institutional investor). Similarly, Table 7 provides information on the incidence of groups that form where competition exists for lead plaintiff at the lead plaintiff hearing (Group_Competition; $5.2 \%$ of the cases) and groups that form where no competition exists at the lead plaintiff hearing (Group_No_Competition; $8.7 \%$ of cases). Table 7 also provides a cross-tabulation of Group_Non-Institution and Group_Institution versus Group_No_Competition and Group_Competition.

\section{Determinants of Attorney Agency Costs}

Prior studies report that institutional investors, and public pension funds in particular, correlate with greater settlement amounts (Choi, Fisch and Pritchard, 2005; Cox and Thomas, 2006; and Cox, Thomas and Bai, 2008a). Looking at the settlement outcome as a measure of lead plaintiff effectiveness suffers from a selection bias problem. Two causal explanations exist for the correlation between public pension funds and other institutional investors with higher 
settlement amounts. Public pension funds may push the lead counsel harder to obtain a greater settlement. In contrast, public pension funds may simply have a greater ability to identify companies with large potential damage awards as targets for litigation-leading to a positive correlation between public pension lead plaintiffs and large settlements but not causation.

Because of the selection problem with looking at settlements, I instead focus on two more direct measures of attorney agency costs: the number of hours the lead counsel works on the litigation prior to settlement and the attorney fee bargain struck with the lead counsel. Public pension funds and other institutional investors are unlikely to select litigation based on the expected number of attorney hours or attorney fees. This section describes the control variables and then reports the results of the agency cost tests.

\subsection{Control Variables}

Both the number of hours worked by attorneys in any particular case and the negotiated attorney fee will turn on the strength of the underlying case, captured by a number of "Case Strength" controls. Case Strength controls include the nature of the substantive allegation. As reported in Panel A of Table 1, the vast majority of complaints (95.9\% of the class actions) allege an antifraud violation under Rule 10b-5 of the Securities Exchange Act of 1934. Complaints that allege a $\S 11$ claim under the Securities Act of 1933 (Section 11) (14.7\% of the class actions) - relating to material misstatements and certain omissions in the registration statement used in a public offering of securities - provide plaintiffs an easier ability compared with under Rule 10b-5 to prove the elements of the cause of action and thus obtain liability. Complaints alleging a $\S 14(a)$ claim under the Securities Exchange Act of 1934 (Section 14) are rare (only $0.2 \%$ of the class actions) and involve antifraud claims relating to proxy statements. 
Case Strength controls include public indicia of wrongdoing or problems in the company at issue in the class action. ${ }^{12}$ These indicia include whether the complaint refers to an accounting restatement covering at least part of the class period (Restatement) or the presence of a SEC or other governmental investigation or enforcement action relating to the fraud at issue (Gov_Investigation). I also look for whether the complaint indicates the termination or resignation of a top officer of the company (Officer_Terminated) or the termination or resignation of the auditor (Auditor_Terminated), and whether the complaint alleges insider trading (Insider Trading Claim). Such indicia make it more likely in a Rule 10b-5 action that the complaint will meet the heightened pleading with particularity requirements for such actions and thus survive the motion to dismiss. Even for non-Rule 10b-5 allegations, the indicia may cause litigants to expect a greater likelihood that the plaintiff will prevail at trial and obtain significant damages. Reference to these indicia in the plaintiffs' complaint provides a signal that the plaintiffs' attorneys viewed such indicia as important for their case.

Case Strength controls also include the market value of equity measured at the end of the fiscal year preceding the beginning of the class period (Market Capitalization), share turnover during the class period (Turnover) and the minimum one-day return during the class period plus the day after the end of the class period (Minimum Return) for the company at issue in the complaint. These variables are correlated with the amount of potential damages investors may obtain in a securities class action (e.g., Francis et al. 1994; Jones and Weingram 1996). The greater the market capitalization, the more money the firm will generally have to satisfy any judgment (particularly if liability insurance limits are reached). The greater the turnover (which

\footnotetext{
${ }^{12}$ For each class action, I collected data from the last filed consolidated class complaint. Where a consolidated complaint was not available, I collected data from the last filed complaint on file with the Stanford Securities Class Clearinghouse.
} 
increases with class period length) and minimum return, the greater is the computed damage measure under Rule 10b-5 and, as a result, the expected attorney fees.

The paper uses several corporate governance variables as control variables ("Corporate Governance" controls). Companies with stronger corporate governance, at least arguably, may pose a lower risk for fraud and thus prove a harder target for plaintiffs in a securities class action. From the proxy statement filed with the SEC immediately prior to the filing of suit, I collected the independent directors as a fraction of the total number of directors (Independent_Board). Independent directors are defined as outside directors without any consulting, familial, prior employment, or other financial relationship with the company or its executive officers. I collected whether a non-executive chairperson sits on the board (Outside_Chair). I also collected the average number of other public company boards on which the outside directors sit (Other_Boards). Directors who sit on many boards may have less time to focus on the governance of any one company. Panel B of Table 1 reports summary statistics on the Case Strength and Corporate Governance controls. Appendix A provides definitions for the variables.

\subsection{Hours Worked}

The first measure for the degree of attorney agency cost is the number of hours the attorneys work on a securities class action. I obtain data on the number of hours worked from attorney fee motions submitted as part of settlements in the dataset. In deciding how vigorously to work, attorneys face a cost-benefit analysis. Attorney fee motions in the dataset uniformly request a fee not based on the hours the attorneys worked or a corresponding lodestar calculation but instead based on a percentage of the recovery. While working greater hours directly increases the attorneys' cost, it has only a fractional beneficial effect for the attorney (through the 
increased likelihood of a greater settlement of which the attorney gets only a percentage of typically $331 / 3 \%$ or less). Where agency costs are greater, attorneys should work fewer hours.

To test the relationship between the proxies for greater (or weaker) lead plaintiff control over the lead counsel, I use multivariate models that focus on (a) the composition of the selected lead plaintiff and (b) the selection process for the lead plaintiff.

\subsubsection{Lead Plaintiff Composition}

To test the impact of the composition of the lead plaintiff on plaintiffs' attorney hours, I estimate the following base model (using ordinary least squares on case-level data with robust standard errors):

$$
\begin{aligned}
& \ln \left(1+\text { Hours }_{\mathrm{i}}\right)=\alpha+\beta_{1 \mathrm{i}} \text { Many_Lead_Plaintiff }_{\mathrm{i}}+\beta_{2 \mathrm{i}} \text { All_Institutional }{ }_{\mathrm{i}} \\
& +\beta_{3 \mathrm{i}} \text { Mixed_Institutional }_{\mathrm{i}}+\beta_{4 \mathrm{i}} \text { LowLoss }_{\mathrm{i}}+\beta_{5 \mathrm{i}} \text { Public_Pension }_{\mathrm{i}} \\
& +\beta_{6 \mathrm{i}} \text { Labor_Union }_{\mathrm{i}}+\beta_{7 \mathrm{i}} \text { Freq_Non-Institutional_Movant_LP } \mathrm{P}_{\mathrm{i}} \\
& +\beta_{8 \mathrm{i}} \text { Freq_Institutional_Movant_LP } \mathrm{P}_{\mathrm{i}}+\beta_{9 \mathrm{i}} \text { Top_Attorney } 50_{\mathrm{i}} \\
& +\sum \beta_{\mathrm{ji}} \text { Case_Strength_Controls } \mathrm{ji}_{\mathrm{ji}}+\sum \beta_{\mathrm{ki}} \mathrm{Corp} \_ \text {Gov_Controls } \mathrm{ki}_{\mathrm{ki}} \\
& +\sum \beta_{\mathrm{li}} \text { Circuit_Indicators } \mathrm{li}_{\mathrm{i}}+\varepsilon_{\mathrm{i}}
\end{aligned}
$$

The base model includes an indicator variable for lead plaintiff groups with more than three members (Many_Lead_Plaintiff). The model includes indicator variables for all institutional investor members (All_Institutional) and a mix of institutional and non-institutional investor members (Mixed_Institutional) with non-institutional investor lead plaintiffs as the base category. The base model includes an indicator variable for lead plaintiffs that had a median or lower loss for the group of all lead plaintiffs (LowLoss). I include in the base model indicator variables for whether a public pension fund (Public_Pension) or labor union pension fund (Labor_Union) is a member of the lead plaintiff. I lastly add indicator variables to the base model for whether a member of the selected lead plaintiff is a Frequent Non-Institutional Movant 
(Freq_Non-Institutional_Movant_LP) or a Frequent Institutional Movant (Freq_Institutional_Movant_LP). To test the possibility that plaintiffs' attorney with significant securities class action experience may act with greater efficiency and thereby reduce hours, the model includes an indicator variable if any of the lead counsel in the specific class action participated 50 or more times as a lead counsel in a class action in the dataset-capturing the very largest attorney firms that enjoy the greatest influence over the lead plaintiff and financial resources (Top_Attorney50). Appendix D lists the Top_Attorney50 firms.

The Case Strength controls described above are included to control for the size of the potential damage award and the strength of case (including Section 11, Section 14, Restatement, Gov_Investigation, Officer_Terminated, Auditor_Terminated, Insider Trading Claim, log of Market Capitalization, Minimum Return, Turnover, and High_Tech). ${ }^{13}$ The Corporate Governance controls described above are also included in the model (Independent Board, Outside Chair, and Other Boards). Lastly, indicator variables for the five circuit courts with the most number of securities class action filings in the dataset (the Second, Third, Five, Ninth, and Eleventh Circuits) are included to control for effects specific to these courts (Circuit Indicators). Due to the lack of observations, I do not include fixed effects for the other circuit courts.

Model 1 of Table 8 reports the results of the base model. Some lead plaintiffs received compensatory payments in addition to their pro rata share of the settlement fund after the lead counsel requested for such a payment in the settlement motion and upon court approval. An application for a separate lead plaintiff payment was made in $25.7 \%$ of the settlement and attorney fee motions. ${ }^{14}$ I hypothesize that lead plaintiffs with relatively low losses that also do

\footnotetext{
${ }^{13}$ Note that among those cases that settled, all of the cases that involved a Section 14(a) allegation also involved a Rule 10b-5 allegation.

${ }^{14}$ Most applications were for non-institutional lead plaintiffs: $36.0 \%$ the non-institutional lead plaintiffs submitted an application for a separate compensatory payment; only $17.1 \%$ of the institutional lead plaintiffs submitted a
} 
not expect a separate payment for their lead plaintiff services from the settlement will act less effectively in restraining attorney agency costs. As a proxy for the lead plaintiff's expectation for a separate payment, I look at whether the lead plaintiff negotiated for the lead counsel to submit an application for a separate payment as part of the settlement or attorney fee motions. I define LowLoss_NoPayment to equal 1 if the lead plaintiff has low losses and the lead plaintiff did not negotiate for the lead counsel to submit a separate application to the court for a compensatory lead plaintiff payment; LowLoss_Payment is equal to 1 if the lead plaintiff has low losses and the lead plaintiff did negotiate a separate lead plaintiff payment application. I split LowLoss in the base model into indicator variables for LowLoss_NoPayment and LowLoss_Payment. Model 2 reports the results. To test the difference between institutional and non-institutional investors, I replace LowLoss in the base model with indicator variables for Institutional and Non-Institutional Lead Plaintiffs with claimed losses that are at or below the median for their respective sub-category of lead plaintiffs (LowLoss_Inst and LowLoss_NonInst). Model 3 reports the results. I also replace LowLoss in the base model with variables for Institutional and Non-Institutional Lead Plaintiffs split based on whether the investor expected a separate lead plaintiff payment (as proxied by whether the lead counsel applied for a separate lead plaintiff payment) (LowLoss_Inst_NoPayment, LowLoss_NonInst_NoPayment, LowLoss_Inst_Payment, and LowLoss_NonInst_Payment). Model 4 reports the results.

[Insert Table 8 Here].

In Models 1 through 4 of Table 8, the coefficients on Many_Lead_Plaintiff, All_Institutional, and Mixed_Institutional are not significantly different from zero. Moreover, payment in $98 \%$ of the applications. The median payment (conditional on any payment being approved by a court) was $\$ 8,692$. 
the coefficients on Public_Pension in all four models are not significant. In contrast, the coefficient on Labor_Union is negative and significant at the 5\% level in Model 1, the 10\% level in Models 2 and 4, and at the $<1 \%$ level in Model 3. Unlike for other institutional investors, labor union lead plaintiffs correlate with fewer attorney hours worked compared with the base category of non-institutional investor lead plaintiffs. Despite the assumption behind the PSLRA that institutional investors acting as lead plaintiffs would reduce the agency cost between plaintiffs' attorneys and the class, labor union lead plaintiffs correlate with increased agency costs. The relationship between labor unions and increased agency costs supports anecdotal reports that labor unions may receive indirect kickbacks from certain plaintiffs' attorney firms and may not act vigorously on behalf of the class as a result. ${ }^{15}$

The coefficients on Freq_Non-Institutional_Movant_LP are negative and significant at the $<1 \%$ level in the four models. Non-institutional investors that are frequent movants for lead plaintiff status correlate with lower attorney hours relative to non-frequent non-institutional investors. The coefficients on Freq_Institutional_Movant_LP, in contrast, are not significant in the four models. Repeat relationships between non-institutional investors and plaintiffs' attorneys are more troublesome than repeat relationships between institutional investors and plaintiffs' attorneys.

The coefficient on LowLoss in the base model (reported as Model 1) is negative but not significantly different from zero. ${ }^{16}$ In Model 2, the coefficient on LowLoss_NoPayment is negative and but beyond standard statistical significance at the $13.1 \%$ level. In contrast, the

\footnotetext{
${ }^{15}$ Fisher (2006) reports that Bill Lerach, a prominent plaintiffs' attorney at Milberg Weiss and then Lerach Coughlin during the time period of this study, "represents ... labor unions, particularly those in the corruption-infested construction trades. A strong supporter of the Democratic party, Lerach has aligned himself tightly with these unions by handing over handsome contributions to their political causes and sharing fees with their outside law firms." For example, in 2004, Fisher reports that Lerach donated \$1.3 million to an AFL-CIO Building Trades political fund.

${ }^{16}$ As a robustness test, I define LowLoss_OneMillion as equal to 1 if the lead plaintiff suffered a loss of $\$ 1$ million or less and 0 otherwise. I replace LowLoss with LossLoss_OneMillion in the base model. Unreported, the coefficient on LowLoss_OneMillion is not significantly different from zero.
} 
difference between the coefficients on LowLoss_NoPayment and LowLoss_Payment is significant at the $10 \%$ level, indicating that low loss plaintiffs that expect no payment correlate with fewer hours than low loss plaintiffs that expect a separate payment. Note also that the coefficient on LowLoss_NonInst_NoPayment (in Model 4) is negative and significant at the 5\% level; the difference between the coefficients on LowLoss_NonInst_NoPayment and LowLoss_NonInst_Payment is significant at the $10 \%$ level. Non-institutional lead plaintiffs with low losses that do not expect a separate payment from the class correlate with fewer hours worked by the plaintiffs' attorneys. ${ }^{17}$ The coefficients on LowLoss_Inst_NoPayment and LowLoss_Inst_Payment in contrast are not significant. The relationship between low losses and higher attorney agency costs applies most strongly for non-institutional investors. The relationship between the number of attorney hours and whether a plaintiffs' attorney chooses to request a separate lead plaintiff payment, however, may be endogenous. It is possible that attorneys who work a greater number of hours will find it easier to justify a separate lead plaintiff payment (because a judge may view the large number of hours worked as indicative of a good outcome for investors and thus that the lead plaintiff is more deserving of a separate payment). I lack an instrument for the expectation of a separate lead plaintiff payment and thus am unable to rule out the possibility of endogeneity. Nonetheless, neither the incidence nor the dollar amount of the separate lead plaintiff payment is significantly correlated with the absolute size of the settlement or the settlement to market capitalization ratio. ${ }^{18}$ This indicates that courts

\footnotetext{
${ }^{17}$ It is possible that attorneys may inflate their hours in the attorney fee motions. I cannot observe the decision to fabricate hours. However, I have no reason to believe that the propensity to fabricate hours is correlated with the lead plaintiff composition and selection process variables of interest in this paper. If anything, lead plaintiffs with weaker control over the plaintiffs' attorneys may result in a greater propensity on the part of the plaintiffs' attorneys to over-report their hours. This tendency will bias against finding a result that lead plaintiffs with weaker control correlate with reduced attorney hours.

${ }^{18}$ The correlation coefficients between the settlement amount and the separate lead plaintiff payment amount is equal to 0.06 , between the settlement amount and the incidence of a separate lead plaintiff payment is equal to 0.05 , between the settlement amount to market capitalization ratio and the separate lead plaintiff payment amount is equal
} 
are not more likely to grant a separate lead plaintiff payment when the litigation results in a favorable outcome for investors. ${ }^{19}$

A possible selection bias may exist in the models of Table 8. Observable data exists on the number of attorney hours only where settlement occurs. ${ }^{20}$ The decision to settle, however, is not random. I employ a Heckman two-stage correction using as an instrument in the first stage selection model (between settlement and non-settlement) the total number of securities class actions filed in the dataset time period for the district court in which the specific class action is filed (Heckman, 1979). I assume this variable is correlated with the decision to settle. A particular district court with large numbers of securities class action may face greater pressure to dismiss such actions to clear their docket, leading to fewer settlements. On the other hand, I assume this variable is not correlated directly with the number of attorney hours worked in settled litigation. For the second stage, I re-estimate the models of Table 8 . The coefficients had the same signs as those in the ordinary least squares model reported in Table 8; while I do not report the coefficients, I report the significance of the Heckman coefficients in Table 8. The Heckman models returned the same qualitative results as the OLS models in Table 8. If anything, the coefficients are more significant in the Heckman models. In the Heckman

to -0.05 , and between the settlement amount to market capitalization ratio and the the incidence of a separate lead plaintiff payment is equal to -0.05 .

${ }^{19}$ It is also possible that plaintiffs' attorneys may request a separate lead plaintiff compensatory payment to reward lead plaintiffs who cater to the preferences of the plaintiffs' attorneys. The mean hours for attorneys where a request for a separate lead plaintiff payment was made were significantly greater (indicating greater attorney effort) than the mean hours for attorneys where no such request was made, supporting the view that the payments were not driven by lead counsel seeking to bribe the lead plaintiff to further the lead counsel's interests. Even if some payments are made to lead plaintiffs catering to the preferences of the lead plaintiffs' attorneys, excluding such lead plaintiffs from the LowLoss_NoPayment subset of lead plaintiffs will bias against finding increased agency costs for the LowLoss_NoPayment subset.

${ }^{20}$ Other possible selection effects exist. I only observe cases that are filed. If the decision to file a suit is correlated with the relationship between lead plaintiff composition and selection and attorney agency costs, then my results may be biased. Nonetheless, in an analysis of case outcomes (high value settlement versus nuisance-level settlements or dismissal), Choi (2007) reports no qualitative change in his results when controlling for the decision to file selection effect. Plaintiffs' attorneys also have a choice of forum. Cox, Thomas, and Bai (2008b), however, report that most forum selection decisions are largely driven by geographical convenience and are thus unlikely to be correlated with the variables of interest in this paper. 
estimation of Model 3 of Table 8, for example, the coefficient on LowLoss_NonInst is negative and now significant at the $10 \%$ level — consistent with the view that non-institutional investors with low losses correlate with higher attorney agency costs. ${ }^{21}$

Not all class actions are the same. Some class actions may settle earlier than others due to factors unrelated to the lead plaintiffs' ability to monitor the effort level of the attorneysleading to fewer attorney hours. While the models in Table 8 include case specific controls, these controls may not capture all the factors that may affect the time to settlement. One omitted factor is whether the litigation is frivolous versus meritorious. Plaintiffs' attorneys involved in frivolous litigation have incentives to expend far lower resources in litigating the case compared with more meritorious litigation (where greater investigation may help develop the strength of the case). I predict that the relationship between the lead plaintiff and the amount of attorney hours will therefore be significant only for non-frivolous litigation. I re-estimate the models in Table 8 for those suits that settled for $\$ 4$ million or more, corresponding to non-nuisance value, and those suits that settled for less than $\$ 4$ million, corresponding to nuisance value. ${ }^{22}$ Unreported, in the nuisance-suit models the coefficients on LowLoss_NoPayment, LowLoss_NonInst_NoPayment, and Labor_Union are all insignificant. ${ }^{23}$ In contrast, the nonnuisance models provide qualitatively similar results as the models in Table 8 . In the nonnuisance suit models, the coefficient on LowLoss_NonInst_NoPayment is negative and now significant at the $<1 \%$ level. The coefficient on Freq_Non-Institutional_Movant_LP remains

\footnotetext{
${ }^{21}$ Similarly, the coefficient on LowLoss_NoPayment in Model 2 is negative and now significant at the $<1 \%$ level. The coefficient on LowLoss_NonInst_NoPayment is negative and now significant at the $<1 \%$ level. The coefficients on Labor_Union remain negative and are now significant at the 5\% level in Models 2 and 3 and at the $<1 \%$ in Model 4. The coefficients on Freq_Non-Institutional_Movant_LP remains negative and is now significant at the 5\% level in Model 1 and the $<1 \%$ level in Models 2 through 4.

${ }^{22}$ See Grundfest (1995: 742-43). I use the \$2.5 million cutoff Grundfest proposes adjusted into 2005 dollars and round up to $\$ 4$ million for the nuisance suit cutoff used in this paper.

${ }^{23}$ I omitted the corporate governance controls and the circuit court indicators variable from the nuisance suit-only models due to the small number of data points (24 observations). The Freq_Non-Institutional_Movant_LP variable was also dropped due to a lack of observations.
} 
negative and significant at the $<1 \%$ in all the models. The coefficient on Labor_Union, however, is not significant in the non-nuisance suit models.

\subsubsection{Lead Plaintiff Selection Process}

The base model to test the impact of the lead plaintiff selection process on attorney hours worked uses the same independent variables as the lead plaintiff composition base model in (2) above. In addition, the base model for the lead plaintiff selection process uses the number of lead plaintiff motions (Number_Separate_Motions) as an independent variable to test the importance of the competitive environment for lead plaintiff. I also include in the base model the number of motions that were withdrawn (Number_Withdraw). The model is as follows (estimated using ordinary least squares on case-level data with robust standard errors):

$$
\begin{aligned}
\ln \left(1+\text { Hours }_{\mathrm{i}}\right) & =\alpha+\beta_{1 \mathrm{i}} \text { Many_Lead_Plaintiff }_{\mathrm{i}}+\beta_{2 \mathrm{i}} \text { All_Institutional } \\
& +\beta_{3 \mathrm{i}} \text { Mixed_Institutional }_{\mathrm{i}}+\beta_{4 \mathrm{i}} \text { Number_Separate_Motions }_{\mathrm{i}} \\
& +\beta_{5 \mathrm{i}} \text { Number_Withdraw }_{\mathrm{i}}+\beta_{6 \mathrm{i}} \text { Top_Attorney50 }_{\mathrm{i}} \\
& +\sum \beta_{\mathrm{ji}} \text { Case_Strength_Controls }_{\mathrm{ji}}+\sum \beta_{\mathrm{ki}} \text { Corp_Gov_Controls } \\
& +\sum \beta_{\mathrm{ki}} \text { Circuit_Indicators }_{\mathrm{li}}+\varepsilon_{\mathrm{i}}
\end{aligned}
$$

Model 1 of Table 9 reports the results of the base model. I replace Number_Withdraw with the Group_Competition and Group_No_Competition indicator variables to examine the importance of side deals in the formation of groups of lead plaintiffs. Model 2 reports the results. I also replace Number_Withdraw with the Group_Non-Institution and Group_Institution variables to assess the difference between aggregating groups of only non-institutional investors compared with groups that include institutional investors. Model 3 reports the results.

[Insert Table 9 Here]. 
In the three models of Table 9, the coefficients on Number_Separate_Motions are positive and significant at the 5\% level. A greater initial competitive environment shifts bargaining strength toward investors away from the plaintiffs' attorneys. Those investors selected lead plaintiff out of a more competitive environment are also possibly better monitors of the selected lead counsel. Model 1 of Table 9 (the base model) also reports that the coefficient on Number_Withdraw, while negative (indicating fewer attorney hours), is significant at the $15.3 \%$ level, beyond conventional levels of statistical significance.

Model 2 of Table 9 reports that the coefficient on Group_Competition is positive and significant at the 5\% level. In contrast, the coefficient on Group_No_Competition is not significantly different from zero. Groups of lead plaintiffs that form where there is no competition — and thus may represent a side deal cut among the competing lead counsel—have no significant impact on the number of hours that the attorneys work compared with nonaggregating lead plaintiffs. On the other hand, groups that form where competition continues to exists for lead plaintiff status correlate with a significant increase in attorney hours compared with non-aggregating lead plaintiffs.

Model 3 of Table 9 reports that the coefficient on Group_Institution is positive and significant at the $<1 \%$ level. In contrast, the coefficient on Group_Non-Institution is not significantly different from zero. Groups of non-institutional lead plaintiff movants do not have a significant effect on attorney hours worked. In contrast, where groups of movants that join together include institutional investors, the number of attorney hours increases significantly. The justification relied on by courts that aggregated groups improve on class welfare applies only for groups lead plaintiffs aggregated in a competitive environment and only for institutional investor movants. Because of potential multicollinearity between Group_Competition and 


\title{
Group_No_Competition variables and the Group_Non-Institution and Group_Institution
}

\author{
variables, I did not estimate the two sets of variables together in the same model. ${ }^{24}$
}

To test the differential effect of the lead plaintiff selection variables for frivolous litigation (where greater attorney hours will likely not improve the case) and meritorious litigation (where greater attorney hours may lead to a stronger case), I re-estimate the models in

\footnotetext{
${ }^{24}$ To control for selection bias in my examination of only attorney hours reported as part of the settlement motion, I estimate a two-stage Heckman model for the three models of Table 9 following the same procedure as above. The coefficients in the second-stage Heckman models had the same signs as those in the models reported in Table 9. While I do not report the coefficients, I report the significance of the Heckman coefficients in Table 9. The qualitative results from the OLS models if anything are strengthened in the Heckman models. The coefficient on Number_Separate_Motions is positive (indicating more hours worked) in the three models but now significant at the $<1 \%$ in Models 1 and 3 (which remaining at the 5\% level in Model 2). The coefficients on Group_Competition and Group_Institution are positive and significant at the 5\% level in Models 2 and 3 respectively.

It is possible that some plaintiffs' attorneys and investors combine to form groups prior to the filing of the lead plaintiff motion. My focus on groups that form after the filing of the lead plaintiff motion may understate the frequency of group formation. To the extent I do not capture all constructed groups in my Group_Institution and Group_Non-Institution variables, my results are biased against finding a significant difference between the Group_Institution and Group_Non-Institution variables and the base category of no aggregating group lead plaintiffs. Most plaintiffs' attorneys, nonetheless, are unlikely to form coalitions with other plaintiffs' attorney firms prior to the filing of the lead plaintiff motion. Prior to the filing of the lead plaintiff motions, an individual plaintiffs' attorney firm will not know the full range of competing motions and thus the value of entering into a coalition with another plaintiffs' attorney firm. As well, an individual plaintiffs' attorney firm will not know the strength of other attorney's lead plaintiff motions prior to the filing. Filing a lead plaintiff motion, moreover, is relatively cost free. Motions may be withdrawn without cost; courts did not reject a motion to withdraw a lead plaintiff motion even once in the dataset class actions. Courts almost always agree to allow aggregation of separately filed lead plaintiff motions when requested by the parties.

Typically when a coalition forms between separate potential lead plaintiffs, the lead counsel for each separate lead plaintiff also combine together as proposed co-lead counsel. The presence of multiple lead counsel in an initial lead plaintiff motion may therefore indicate a coalition formed prior to the filing of the motion. In the dataset, of the 1,087 lead plaintiff motions where data exists on the number of proposed lead counsel is known, 856 (or 78.8\%) contained only one proposed lead counsel firm - indicating that most lead plaintiff motions do not represent a pre-filing coalition. As a robustness test, I redefine a group to exist whenever more than one plaintiffs' attorney firm acts as co-lead counsel (Group_Multiple_Atty_Institution and Group_Multiple_Atty_Non-Insitution respectively). I replace Group_Institution and Group_Non-Institution in Model 3 of Table 9, with Group_Multiple_Atty_Institution and Group_Multiple_Atty_Non-Insitution. Unreported, the model provides qualitatively the same results as in Model 3. The coefficient on Group_Multiple_Atty_Insitution is positive and significant at the $5 \%$ level, indicating that groups of institutional investors correlate with more attorney hours worked. The coefficient on Group_Multiple_Atty_Non-Insitution is not significantly different from zero.

It is also possible that the greater the number of competing motions, the more attorney hours will be spent seeking lead plaintiff and lead counsel status. To control for this possibility, I constructed the ratio of the days spent on the lead plaintiff selection process (the difference between the lead plaintiff selection date and the date of the first filing for lead plaintiff) and the total days between the filing of litigation and the resolution date. I added this ratio to Models 1 through 3 of Table 9. Unreported the coefficient on the day ratio variable is not significantly different from zero in any of the re-estimated models. The models report that same qualitative results for Group_Competition (positive and significant at the $<1 \%$ level) and Group_Institution (positive and significant at the $5 \%$ level). The coefficient on the Num_Separate_Motions however is positive and now significant at only the $10 \%$ level in Models 1 and 3 and at only the $\overline{1} 3.8 \%$ level in Model 2.
} 
Table 9 for those suits that settled for $\$ 4$ million or more, corresponding to non-nuisance value, and those suits that settled for less than $\$ 4$ million, corresponding to nuisance value. Unreported, in the nuisance suit models, the coefficients on Number_Separate_Motions, Number_Withdraw, and Group_Competition are all insignificant. ${ }^{25}$ In contrast, the non-nuisance suit models provided similar results as those in Table 9. In the non-nuisance suit models, the coefficient on Number_Separate_Motions is negative and now significant at the 5\% level (in Models 1 and 3) and $10 \%$ level (in Model 2); the coefficient on Number_Withdraw is negative and now significant at the 5\% level in Model 1; and the coefficient on Group_Competition is positive and significant at the 5\% level. Unlike in Table 9, the coefficient on Group_No_Competition is also positive and significant at the $10 \%$ level—indicating that both groups formed with competition and with no remaining competition correlate with greater attorney hours worked. Lastly, the coefficient on Group_Institution is positive and significant at the $<1 \%$ level, indicating that groups of institutional investor lead plaintiffs correlate also with more attorney hours worked.

\subsection{Attorney Fee Bargain}

The second proxy for the degree of attorney agency cost is the requested attorney fee award negotiated between the lead plaintiff and the lead counsel (measured as a percentage of the settlement amount). I obtain requested attorney fee data from the attorney fee motions filed as part of settlements. Weak lead plaintiffs will allow higher attorney fee motions all other things equal. To test the relationship between the proxies for greater (or weaker) lead plaintiff control over the lead counsel and the attorney fees, I use multivariate models that focus on (a) the composition of the selected lead plaintiff and (b) the selection process for the lead plaintiff.

\footnotetext{
${ }^{25}$ I omitted the corporate governance controls from the nuisance suit only models due to the small number of data points (31 observations). Due to insufficient data points, the Group_Institution variable was also dropped from the nuisance-suit only models.
} 


\subsubsection{Lead Plaintiff Composition}

The base model to test the relationship between lead plaintiff composition and the requested attorney fees uses the same independent variables as the base model for attorney hours detailed in (2) above. In addition, the model includes the log of the settlement amount $(\ln ($ Set_Amount $))$. Prior studies report a close relationship between settlement amount and the attorney fee award (e.g., Eisenberg and Miller, 2004). The attorney fee base model uses the log odds of the requested attorney fee percentage as the dependent variable (estimated using ordinary least squares on case level data with robust standard errors):

$$
\begin{aligned}
& \ln \left(\text { Atty_Fee }_{\mathrm{i}} / 1 \text {-Atty_Fee }{ }_{\mathrm{i}}\right)=\alpha+\beta_{1 \mathrm{i}} \text { Many_Lead_Plaintiff }_{\mathrm{i}}+\beta_{2 \mathrm{i}} \text { All_Institutional }_{\mathrm{i}} \\
& +\beta_{3 \mathrm{i}} \text { Mixed_Institutional }_{\mathrm{i}}+\beta_{4 \mathrm{i}} \text { Low Loss }_{\mathrm{i}} \\
& +\beta_{5 \mathrm{i}} \text { Public Pension }_{\mathrm{i}}+\beta_{6 \mathrm{i}}{\text { Labor } \text { Union }_{\mathrm{i}}} \\
& +\beta_{7 \mathrm{i}} \text { Freq_Non-Institutional_Movant_LP } P_{\mathrm{i}} \\
& +\beta_{8 i} \text { Freq_Institutional_Movant_LP }{ }_{i} \\
& +\beta_{9 \mathrm{i}} \ln \left(\text { Set_Amount }_{\mathrm{i}}\right)+\beta_{10 \mathrm{i}} \text {Top}_{-} \text {Attorney } 50_{\mathrm{i}} \\
& +\sum \beta_{\mathrm{ji}} \text { Case_Strength_Controls } \mathrm{ji}_{\mathrm{ji}} \\
& +\sum \beta_{\mathrm{ki}} \text { Corp_Gov_Controls } \mathrm{ki}_{\mathrm{i}}+\sum \beta_{\mathrm{li}} \text { Circuit_Indicators } \mathrm{li}_{\mathrm{li}}+\varepsilon_{\mathrm{i}}
\end{aligned}
$$

Model 1 of Table 10 reports the results from the base model. I replace LowLoss with LowLoss_NoPayment and LowLoss_Payment to test the importance of both low losses and the expectation of a separate lead plaintiff payment in determining the lead plaintiffs' incentives to check the power of the lead counsel. Model 2 reports the results. I replace LowLoss in the base model with indicator variables for Institutional and Non-Institutional Lead Plaintiffs with claimed losses that are at or below the median for their respective sub-category of lead plaintiffs (LowLoss_Inst and LowLoss_NonInst). Model 3 reports the results. I also replace LowLoss in the base model with variables for Institutional and Non-Institutional Lead Plaintiffs split based on whether the investor expected a separate lead plaintiff payment (LowLoss_Inst_NoPayment, 
LowLoss_NonInst_NoPayment, LowLoss_Inst_Payment, and LowLoss_NonInst_Payment).

Model 4 reports the results.

[Insert Table 10 Here].

In Models 1 through 4 of Table 10, the coefficients on Many_Lead_Plaintiff, All_Institutional, Mixed_Institutional are not significant. Similarly, the coefficients on Public_Pension and Labor_Union are not significant in the four models. Unlike for attorney hours, labor unions are not correlated with attorney fees. In contrast, the coefficients on Freq_Institutional_Movant_LP are negative and significant at the 10\% level in Models 1 through 4. Institutional investors that are frequent movants for lead plaintiff develop repeat relationships with attorney firms. This repeat relationship correlates with a lower attorney fee when the institution is selected as lead plaintiff, indicating that such institutions enjoy bargaining strength. Alternatively, frequent institutional movants may be more predisposed to engaging in activism and thus take a more active role in negotiating with the lead plaintiffs' attorney. ${ }^{26}$ In contrast, the coefficients on Freq_Non-Institutional_Movant_LP are not significant. Frequent noninstitutional movants that are selected lead plaintiff do not exhibit any increase in bargaining strength; if anything, they correlate with higher attorney fees.

In Model 1, the coefficient on LowLoss is positive and significant at the $10 \%$ level. In Model 2, the coefficient on LowLoss_NoPayment is positive and significant at the 5\% level. Where lead plaintiffs suffer only low absolute dollar losses, the lead plaintiffs are less effective

\footnotetext{
${ }^{26}$ An alternate explanation for the correlation between frequent institutional investor movants and lower fees is possible. Institutional investors typically will enjoy greater ability, expertise, and resources with which to monitor plaintiffs' attorneys. Compared with institutional investors, individuals and other non-institutional investors may need to use additional motivation to get plaintiffs' attorneys to provide the same level of effort. Higher fees may get plaintiffs' attorneys to work harder for the class - allowing the plaintiffs' attorney to capture a greater portion of any marginal benefit from additional work. The correlation between higher attorney fees and non-institutional investors may therefore simply represent the best deal the non-institutional investor lead plaintiff could strike on behalf of the class. This alternate explanation, nonetheless, does not explain why lead plaintiffs with lower losses grant higher attorney fees or why non-frequent movant institutional investors (who presumably also have greater resources and expertise compared with non-institutional investors) do not correlate with lower attorney fees.
} 
in obtaining lower fees compared with lead plaintiffs that suffered greater losses-particularly where the lead plaintiffs do not expect a separate payment. On the other hand, the difference between LowLoss_NoPayment and LowLoss_Payment is not significant. The coefficients on LowLoss_Inst and LowLoss_NonInst in Model 3 and on LowLoss_Inst_NoPayment and LowLoss_NonInst_NoPayment in Model 4 are not significantly different from zero. ${ }^{27}$

\subsubsection{Lead Plaintiff Selection Process}

To test the importance of the lead plaintiff selection process, I use the following base model with the log-odds of the requested attorney fee percentage as the dependent variable (estimated using ordinary least squares on case level data with robust standard errors):

$$
\begin{aligned}
& \ln \left(\text { Atty_Fee }_{\mathrm{i}} / 1 \text {-Atty_Fee }{ }_{\mathrm{i}}\right)=\alpha+\beta_{1 \mathrm{i}} \text { Many_Lead_Plaintiff }_{\mathrm{i}}+\beta_{2 \mathrm{i}} \text { All_Institutional }{ }_{\mathrm{i}} \\
& +\beta_{3 \mathrm{i}} \text { Mixed_Institutional }_{\mathrm{i}}+\beta_{4 \mathrm{i}} \text { Number_Separate_Motions }_{\mathrm{i}} \\
& +\beta_{5 \mathrm{i}} \text { Number_Withdraw }_{\mathrm{i}}+\beta_{6 \mathrm{i}} \ln \left(\text { Set_Amount }_{\mathrm{i}}\right) \\
& +\beta_{7 \mathrm{i}} \text { Top_Attorney50 } 0_{\mathrm{i}}+\sum \beta_{\mathrm{ji}} \text { Case_Strength_Controls } \mathrm{ji}_{\mathrm{i}} \\
& +\sum \beta_{\mathrm{ki}} \text { Corp_Gov_Controls } \mathrm{ki}_{\mathrm{i}}+\sum \beta_{\mathrm{li}} \text { Circuit_Indicators }_{\mathrm{li}}+\varepsilon_{\mathrm{i}}
\end{aligned}
$$

\footnotetext{
${ }^{27}$ As with the attorney hours worked model, a possible selection bias may exist. Data exists on attorney fees only where settlement occurs. I employ a Heckman two-stage correction using the total number of securities class actions filed in the dataset time period for the district court in which the specific class action is filed as an instrument in the first stage selection model (between settlement and non-settlement). The coefficients in the second-stage Heckman models had the same signs as those in the ordinary least squares model reported in Table 10. While I do not report the coefficients, I report the significance of the Heckman coefficients in Table 10. The results of the second-stage Heckman model are qualitatively the same as in Table 10. In the second-stage Heckman models (that correspond to the models in Table 10), the coefficient on LowLoss is negative and now significant at the 5\% level. The coefficient on LowLoss_NoPayment is negative and significant at the 5\% level. The coefficient on Freq_Institutional_Movant_LP remains negative but is now significant at the $10 \%$ level in Model 1 and at the 5\% level in Models 3 and 4.

To control for non-linearities in the relationship between the requested attorney fees and the settlement amount, I re-estimated the models in Table 10 with the substitution of Set_Amount instead of $\ln$ (Set_Amount) and the addition of Set_Amount ${ }^{\wedge} 2$ as an independent variable. The results were qualitatively the same. The coefficient on LowLoss is positive and significant at the $10 \%$ level in Model 1. The coefficient on LowLoss_NoPayment is positive and significant at the 5\% level. The coefficient on Frequent_Institutional_Movant_LP is negative and significant at the $10 \%$ level in Models 1, 2, and 3.

As a robustness test, I define LowLoss_OneMillion as equal to 1 if the lead plaintiff suffered a loss of $\$ 1$ million or less and 0 otherwise. I replace LowLoss with LossLoss_OneMillion in the base model. Unreported, the coefficient on LowLoss_OneMillion is positive and significant at the $5 \%$ level.
} 
The base model uses the same independent variables as the base model in (4) with the addition of Number_Separate_Motions and Number_Withdraw. The greater the number of competing motions, the more is the competitive pressure on the plaintiffs' attorneys. In contrast, the more motions that were withdrawn, the more likely that the lead plaintiff was selected out of a compromise among plaintiffs' attorneys, indicating greater plaintiffs' attorney power relative to the selected lead plaintiff. Model 1 of Table 11 reports the results of the base model. I replace Number_Withdraw in the base model with the Group_Competition and Group_No_Competition indicator variables to examine the importance of side deals in the formation of groups of lead plaintiffs. Model 2 reports the results. To the base model, I replace Number_Withdraw with the Group_Non-Institution and Group_Institution indicator variables to assess the difference between institutional investors compared with non-institutional investors that come together in a group of lead plaintiffs. Model 3 reports the results.

[Insert Table 11 Here].

Table 11 provides evidence on the significance of the presence of institutional investors as lead plaintiff. The coefficient on All_Institutional is negative (indicating lower attorney fees compared with non-institutional investor lead plaintiffs) and significant at the 5\% level in Model 2 and the $10 \%$ level in Models 1 and 3. The coefficient on Number_Separate_Motions is negative but only significant (at the 10\% level) in Model 3, providing only limited evidence that greater competition for lead plaintiff correlates with lower attorney fees.

Model 1 of Table 11 reports that the coefficient on Number_Withdraw is not significantly different from zero. I find no evidence that greater numbers of withdrawn motions correlates with higher attorney fees. Model 2 reports that the coefficients on Group_Competition and Group_No_Competition are not significantly different from zero. I find no evidence that side 
deals among attorneys results in group of lead plaintiffs who have greater bargaining strength in negotiating the attorney fee award. In contrast, Model 3 reports that the coefficient on Group_Institution is negative and significant at the 5\% level. The coefficient on Group_NonInstitution is not significantly different from zero. Evidence exists, therefore, that groups that include institutional investors are more effective in generating lower attorney fees compared with groups of non-institutional investors. Institutional investors that are willing to join in groups may be predisposed more generally toward activism, leading them to negotiate more vigorously with plaintiffs' attorneys over fees. Aggregated groups of non-institutional investors, on the other hand, do not perform appreciably better than single movant non-institutional investors. (Perhaps because in either case, plaintiffs' attorneys dominate over the non-institutional investor lead plaintiffs). At least for non-institutional investors, I find no support for the justification given by courts that appointing aggregated groups of previously competing movants as co-lead plaintiffs will further the interests of the class of investors. ${ }^{28}$

\section{Conclusion}

\footnotetext{
${ }^{28}$ To control for selection bias in examining only settlement-related data, I estimate a two-stage Heckman model for Models 1 through 3 following the same procedure as for the Heckman two-stage model in Table 9. The coefficients in the second-stage Heckman models had the same signs as those in the ordinary least squares model reported in Table 11. While I do not report the coefficients, I report the significance of the Heckman coefficients in Table 11. The qualitative results in the Heckman models remain the same-if anything with greater statistical significance. The coefficient on All_Institutional is negative and now significant at the 5\% level in all three models. The coefficient on Number_Separate_Motions is negative and is now significant at the 5\% in Model 1 and the $10 \%$ level in Model 3. Group_Competition is negative and now significant at the 5\% level in Model 2. Group_Institution is negative and now significant at the $<1 \%$ level in Model 3.

As a robustness test, I redefine a group to exist whenever more than one plaintiffs' attorney firm acts as colead counsel regardless of whether aggregating motions formed the group or not (Group_Multiple_Atty_Institution and Group_Multiple_Atty_Non-Institution respectively). I replace Group_Institution and Group_NonInst in Model 3 of Table 11, with Group_Multiple_Atty_Institution and Group_Multiple_Atty_Non-Institution. Unreported, the coefficients on Group_Multiple_Atty_Institution and Group_Multiple_Atty_Non-Institution are not significant. Unlike the results in Model 3 of Table 11, coalitions of attorneys do not correlate with attorney fees.

As a control for possible non-linearities in the relationship between the requested attorney fees and the settlement amount, I re-estimated the models in Table 11 with Set_Amount instead of $\ln$ (Set_Amount) and the addition of the square of Set_Amount as an independent variable. The results were qualitatively the same.
} 
The evidence in the paper suggests that the PSLRA adopts too blunt an approach in applying the presumption for lead plaintiff. Rather than focus solely on the largest financial stake at interest, courts should devote attention to the composition of the lead plaintiff and how the lead plaintiff is selected. Even the lead plaintiff with the largest financial stake in the relief from the litigation may not have strong incentives if the lead plaintiff suffered only a low absolute loss (particularly where the lead plaintiff does not expect any separate compensation for its efforts). Courts should be wary of approving the aggregation of groups of non-institutional investors that may simply represent a bargain struck among plaintiffs' attorneys rather than the best representative for the class. Such groups do not correlate with improved agency costs compared with single movant non-institutional investors. While the legislative history of the PSLRA focuses on institutional investors, the provisions of the PSLRA only acknowledge the importance of institutional investors indirectly through the largest financial interest presumption of lead plaintiff. The paper reports evidence that institutional investors, particularly when acting in groups, correlate with significantly lower attorney agency costs. On the other hand, labor union pension funds do not follow this general trend and may, in fact, correlate with increased agency costs. The paper also provides justification for the PSLRA's limit on frequent lead plaintiffs only in the case of non-institutional investors. In contrast, frequent institutional lead plaintiffs may use their expertise and repeat relationship with attorneys to bargain for lower fees and to monitor the attorneys, leading to more attorney hours worked. 


\section{References}

Alexander, Janet Cooper. 1991. Do the Merits Matter? A Study of Settlements in Securities Class Actions, 43 Stan. L. Rev. 497.

Barrett, William P. 1993. Bold, brash William Lerach is the scourge of Silicon Valley and friend to lots of politicians, Forbes, October 11, 1993 at p. 52.

Bohn, James, and Stephen Choi. 1996. Fraud in the New-Issues Market: Empirical Evidence on Securities Class Actions, 144 University of Pennsylvania Law Review 903-82.

Choi, Stephen J., Jill E. Fisch \& A.C. Pritchard. 2005. Do Institutions Matter? The Impact of the Lead Plaintiff Provision of the Private Securities Litigation Reform Act, 83 Wash. U. L.Q. 869.

Coffee, Jr., John C. 1983. Rescuing the Private Attorney General: Why the Model of the Lawyer as Bounty Hunter Is Not Working, 42 Md. L. Rev. 215.

Cox, James D., Randall S. Thomas \& Lynn Bai. 2008a. There Are Plaintiffs And ... There are Plaintiffs: An Empirical Analysis of Securities Class Action Settlements, 61 Vanderbilt Law Review 355-386.

Cox, James D., Randall S. Thomas \& Lynn Bai. 2008b. Do Differences in Pleading Standards Cause Forum Shopping in Securities Class Actions?: Doctrinal and Empirical Analyses (working paper, 2008).

Cox, James D. and Randall S. Thomas with Dana Kiku. 2008. Does the Plaintiff Matter? An Empirical Analysis of Lead Plaintiffs in Securities Class Actions, Columbia Law Review 106: 1587-1640.

Creswell, Julie. 2007. Ex-Partner at Milberg Pleads Guilty to Conspiracy, New York Times, July $10,2007$.

Grundfest, Joseph A. 1995. Why Disimply, Harvard Law Review 108: 963-1024 (1995).

Heck, R. Chris. 1999. Conflict and Aggregation: Appointing Institutional Investors as Sole Lead Plaintiffs Under the PSLRA, University of Chicago Law Review 66: 1199-1230.

Heckman James J. 1979. "Sample Selection Bias as a Specification Error," 47 Econometrica 153-61.

Eisenberg, Theodore and Geoffrey P. Miller. 2004. Attorney Fees in Class Action Settlements: An Empirical Study. Journal of Empirical Legal Studies 1:27-78.

Fisher, Daniel. 2006. Securities lawyer Bill Lerach crusades for corporate justice. But What about the shady records of his union allies? Forbes, February 13, 2006 p. 102. 
Francis, J., D. Philbrick, and K. Schipper. 1994. Shareholder litigation and corporate disclosures. Journal of Accounting Research 32: 137-164.

H.R. Rep. No. 104-369, $104^{\text {th }}$ Cong., $1^{\text {st }}$ Sess. (1995).

Johnson, M. F., K. K. Nelson \& A. C. Pritchard. 2007. Do the Merits Matter More? The Impact of the Private Securities Litigation Reform Act, 23 J. of Law, Economics \& Organization 627.

Jones, C. L., and S. E. Weingram. 1996. The determinants of 10b-5 litigation risk. Working paper, Stanford Law School.

McCahery, Joseph A., Zacharias Sautner and Laura T. Starks, Behind the Scenes: The Corporate Governance Preferences of Institutional Investors (Working Paper, 2008).

Perino, Michael A. 2006. Institutional Activism Through Litigation: An Empirical Analysis of Public Pension Fund Participation in Securities Class Actions (St. John's Legal Studies Research Paper Series).

PricewaterhouseCoopers. 2003. 2003 Securities Litigation Study. Manuscript available at www.10b5.com.

Private Securities Litigation Reform Act, 109 Stat. 737 (1995) (codified as amended in scattered sections of 15 U.S.C.).

Selvin, Milly. 2008. Plaintiff-for-hire sentenced: A retired lawyer gets home detention in the Milberg Weiss case, Los Angeles Times, January 29, 2008.

Simmons, Laura E. and Ellen M. Ryan. 2005. Post-Reform Act Securities Settlements. Cornerstone Research.

Weiss, Elliott J. and John S. Beckerman. 1995. Let the Money Do the Monitoring: How Institutional Investors Can Reduce Agency Costs in Securities Class Actions, 104 Yale L.J. 2053. 


\section{Table 1}

Panel A: Dataset Description

\begin{tabular}{lcc}
\hline Year of Suit Filing & Frequency & Fraction of all Cases \\
\hline 2003 & 156 & 0.324 \\
2004 & 180 & 0.373 \\
2005 & 146 & 0.303 \\
Total & 482 & 1.000 \\
\hline Claims & Frequency & Fraction of all Cases \\
\hline Rule 10b-5 of the Securities Exchange Act of 1934 & 462 & 0.959 \\
Section 11 of the Securities Act of 1933 & 71 & 0.147 \\
Section 14(a) of the Securities Exchange Act of 1934 & 11 & 0.002 \\
Total & 482 & 1.000 \\
\hline & & Fraction of all Cases \\
\hline Outcome & Frequency & 0.396 \\
Settlement & 191 & 0.008 \\
Dismissal & 4 & 0.434 \\
Trial Verdict for Plaintiff & 209 & 0.002 \\
Unknown (or Not Decided) & 1 & 0.160 \\
\hline
\end{tabular}




\section{Table 1}

Panel B: Summary Statistics of Control Variables Used in Multivariate Tests

\begin{tabular}{|c|c|c|c|c|c|}
\hline Variable & Mean & $25 \%$ & $50 \%$ & $75 \%$ & Stand. Dev. \\
\hline Requested Attorney Fee & 0.270 & 0.250 & 0.275 & 0.300 & 0.050 \\
\hline Hours & 5306.4 & 1531.0 & 2621.5 & 5200.0 & 10492.8 \\
\hline Settlement Amount (\$ mill) & 19.834 & 2.575 & 5.500 & 10.500 & 93.313 \\
\hline Section 11 & 0.147 & 0.000 & 0.000 & 0.000 & 0.355 \\
\hline Section 14 & 0.002 & 0.000 & 0.000 & 0.000 & 0.150 \\
\hline Restatement & 0.338 & 0.000 & 0.000 & 1.000 & 0.474 \\
\hline Gov_Investigation & 0.207 & 0.000 & 0.000 & 0.000 & 0.406 \\
\hline Officer_Terminated & 0.299 & 0.000 & 0.000 & 1.000 & 0.458 \\
\hline Auditor_Terminated & 0.066 & 0.000 & 0.000 & 0.000 & 0.248 \\
\hline Insider Trading Claim & 0.558 & 0.000 & 1.000 & 1.000 & 0.497 \\
\hline Market Cap. (\$ mill) & 6311.9 & 151.7 & 549.0 & 2342.9 & 21013.9 \\
\hline Minimum Return & -0.276 & -0.365 & -0.260 & -0.170 & 0.146 \\
\hline Turnover & 0.849 & 0.811 & 0.966 & 0.998 & 0.233 \\
\hline High_Tech & 0.172 & 0.000 & 0.000 & 0.000 & 0.378 \\
\hline Independent Board & 0.631 & 0.500 & 0.667 & 0.750 & 0.176 \\
\hline Outside Chair & 0.180 & 0.000 & 0.000 & 0.000 & 0.385 \\
\hline Other Boards & 6.163 & 1.000 & 5.000 & 9.000 & 6.103 \\
\hline
\end{tabular}

Variable definitions in Appendix A. 
Table 2

Selected Lead Plaintiff

\begin{tabular}{lccccc}
\hline & Mean & $\mathbf{2 5 \%}$ & $\mathbf{5 0 \%}$ & $\mathbf{7 5 \%}$ & $\begin{array}{c}\text { Stand. } \\
\text { Dev. }\end{array}$ \\
\hline Number of members in the selected lead plaintiff & & & & & 1.427 \\
$\quad$ Number of members - Inst. Inv. Lead Plaintiff & 0.849 & 0 & 1 & 1 & 1.051 \\
$\quad$ Number of members - Non-Inst. Investor Lead Plaintiff & 1.439 & 0 & 1 & 2 & 1.535 \\
$\quad$ & 0.134 & 0 & 0 & 0 & 0.312 \\
$\begin{array}{l}\text { Lead Plaintiff with Public Pension Fund Member } \\
\text { (Public_Pension) }\end{array}$ & & & & & \\
$\begin{array}{l}\text { Lead Plaintiff with Labor Union Pension Fund Member } \\
\text { (Labor_Union) }\end{array}$ & 0.165 & 0 & 0 & 0 & 0.337 \\
\end{tabular}

\section{Number of Selected \\ Lead Plaintiffs}

Fraction of All
Selected Lead

Plaintiffs

\begin{tabular}{lcc}
\hline All Institutional Lead Plaintiffs (All_Institutional) & 163 & 0.367 \\
Mixed Lead Plaintiffs (Mixed_Institutional) & 85 & 0.191 \\
All Non-Institutional Lead Plaintiffs (NonInst_LP) & 196 & 0.441 \\
Total & 444 & 1.000
\end{tabular}

\section{Table 3}

\section{Lead Plaintiff Claimed Losses}

\begin{tabular}{|c|c|c|c|c|c|}
\hline & Mean & $25 \%$ & $50 \%$ & $75 \%$ & Std. Dev. \\
\hline Lead Plaintiff Loss & 2433.1 & 78.4 & 268.8 & 750.9 & 14400.0 \\
\hline Lead Plaintiff Loss - Institutional & 3897.4 & 148.8 & 374.3 & 1453.8 & 18600.0 \\
\hline Lead Plaintiff Loss - Non-Institutional & 308.3 & 27.9 & 108.1 & 323.2 & 608.2 \\
\hline
\end{tabular}

Losses are in thousands of dollars. 


\section{Table 4}

\section{Frequent Lead Plaintiff Movants}

\begin{tabular}{ccc}
\hline & Number & $\begin{array}{c}\text { Fraction of all } \\
\text { Motions }\end{array}$ \\
\hline Total Number of Motions for Lead Plaintiff in the dataset & 1277 & 1.000 \\
With a Frequent Institutional Movant & 144 & 0.117 \\
With a Frequent Non-Institutional Movant & 40 & 0.033 \\
\hline
\end{tabular}

\begin{tabular}{lccc}
\hline & $\begin{array}{c}\text { Frequent } \\
\text { Institutional } \\
\text { Movant }\end{array}$ & $\begin{array}{c}\text { Frequent } \\
\text { Individual } \\
\text { Movant }\end{array}$ & p-value \\
\hline Fraction of motions that were granted & 0.529 & 0.289 & 0.015 \\
Fraction of motions that were withdrawn & 0.118 & 0.272 & 0.070 \\
Fraction of motions with Most Frequent Attorney & 0.817 & 0.649 & 0.020 \\
\hline & & & 0.010 \\
\hline $\begin{array}{l}\text { Fraction of frequent movants that had at least one motion } \\
\text { with another frequent movant }\end{array}$ & 0.476 & 0.105 & \\
\hline
\end{tabular}

p-value is from two-sided t-test of difference in means. Most Frequent Attorney is defined as the attorney firm that associates with the movant the greatest number of times. Frequent Institutional Movant is defined as an institutional investor that was part of a lead plaintiff motion at least 2 times in the dataset. Frequent Non-Institutional Movant is defined as an individual or non-institutional investor entity that was part of a lead plaintiff motion at least 2 times in the dataset. 


\section{Table 5}

\section{Lead Plaintiff Motions}

\begin{tabular}{lccccc}
\hline & Mean & $\mathbf{2 5 \%}$ & $\mathbf{5 0 \%}$ & $\begin{array}{c}\mathbf{7 5 \%} \\
\text { Stand. } \\
\text { Dev. }\end{array}$ \\
\hline Number of competing lead plaintiff motions per case & 2.840 & 1 & 2 & 4 & 1.995 \\
Number of motions selected per case & 1.153 & 1 & 1 & 1 & 0.431 \\
Number of motions rejected per case & 0.919 & 0 & 0 & 1 & 1.455 \\
Number of motions withdrawn per case & 0.769 & 0 & 0 & 1 & 1.163 \\
\hline
\end{tabular}

\begin{tabular}{lcccc}
\hline & $\begin{array}{c}\text { Number of } \\
\text { Cases }\end{array}$ & $\begin{array}{c}\text { Fraction of } \\
\text { Cases }\end{array}$ & $\begin{array}{c}\text { Number of } \\
\text { Competing } \\
\text { Motions }\end{array}$ & $\begin{array}{c}\text { Fraction } \\
\text { Where } \\
\text { Institutional } \\
\text { Investor Wins }\end{array}$ \\
\hline Institutional Investor Only Motions & 89 & 0.206 & 1.921 & 1.000 \\
Non-Institutional Only Motions & 156 & 0.361 & 1.955 & 0.000 \\
Mixed Motions & 187 & 0.433 & 4.016 & 0.178 \\
Total & 432 & 1.000 & 2.840 & 0.438
\end{tabular}

Mixed Motions are cases where competing motions of non-institutional investors and institutional investors exist for lead plaintiff. 


\section{Table 6}

\section{Lead Plaintiff Group Construction}

\section{Panel A: Competing and Withdrawing Lead Plaintiff Motions}

\begin{tabular}{ccc}
\hline & Number of Cases & Fraction of all Cases \\
\hline No withdrawal of any motion & 236 & 0.546 \\
Withdrawal of at least one motion & 196 & 0.454 \\
Withdraw and No Competition & 106 & 0.245 \\
Withdraw and Competition & 90 & 0.208 \\
Total & 432 & 1.000
\end{tabular}

"Withdraw and No Competition" occurs when at least one motion withdraws and all the remaining movants agree on the lead plaintiff. "Withdraw and Competition" occurs when at least one motion withdraws and at least two movants remain as competitors for lead plaintiff.

\section{Panel B: Movant Withdrawal}

\begin{tabular}{|c|c|c|}
\hline & Model 1 & Model 2 \\
\hline Mid_Attorney & $\begin{array}{c}-0.678^{*} \\
(-2.55)\end{array}$ & $\begin{array}{c}-0.719^{* *} \\
(-2.65)\end{array}$ \\
\hline Bottom_Attorney & $\begin{array}{l}1.014^{+} \\
(1.77)\end{array}$ & $\begin{array}{l}1.005^{+} \\
(1.75)\end{array}$ \\
\hline Number_Attorneys & $\begin{array}{l}-0.430 \\
(-1.43)\end{array}$ & $\begin{array}{l}-0.470 \\
(-1.54)\end{array}$ \\
\hline Number_Movants & & $\begin{array}{c}0.0165 \\
(0.19)\end{array}$ \\
\hline Institutional_Movant_Fraction & & $\begin{array}{l}-0.367 \\
(-0.85)\end{array}$ \\
\hline Frequent_Institutional_Movant & & $\begin{array}{l}-0.199 \\
(-0.37)\end{array}$ \\
\hline Frequent_Non-Institutional_Movant & & $\begin{array}{l}-0.138 \\
(-0.22) \\
\end{array}$ \\
\hline $\begin{array}{l}\mathrm{N} \\
\text { pseudo } \mathrm{R}^{2}\end{array}$ & $\begin{array}{c}313 \\
0.055\end{array}$ & $\begin{array}{c}312 \\
0.061\end{array}$ \\
\hline
\end{tabular}




\section{Table 7}

\section{Aggregation of Lead Plaintiff Movants into Groups}

\begin{tabular}{lcc}
\hline Motion Outcome & Number of Cases & Fraction of All Cases \\
\hline No Aggregation & 417 & 0.865 \\
Aggregation & 67 & 0.139 \\
$\quad$ Group_Non-Institution & 23 & 0.048 \\
Group_Institution & 44 & 0.091 \\
& & \\
Group_Competition & 25 & 0.052 \\
Group_No_Competition & 42 & 0.087 \\
Total & 482 & 1.000 \\
\hline
\end{tabular}

Cross-Tabulation of Group Types

\begin{tabular}{l|cc}
\hline & Group_Competition & Group_No_Competition \\
\hline Group_Non-Institution & 6 & 17 \\
Group_Institution & 19 & 25 \\
\hline
\end{tabular}

Cells contain the number of cases that fit the cross-tabulation categories. 
Table 8: Lead Plaintiff Composition and Attorney Hours

\begin{tabular}{|c|c|c|c|c|}
\hline & Model 1 & Model 2 & Model 3 & Model 4 \\
\hline Many_Lead_Plaintiff & $\begin{array}{l}-0.0106 \\
(-0.04)\end{array}$ & $\begin{array}{c}0.0620 \\
(0.20)\end{array}$ & $\begin{array}{l}0.144 \\
(0.47)\end{array}$ & $\begin{array}{l}0.227 \\
(0.70)\end{array}$ \\
\hline All_Institutional & $\begin{array}{l}0.554 \\
(1.34)\end{array}$ & $\begin{array}{l}0.643^{\mathrm{a}} \\
(1.44)\end{array}$ & $\begin{array}{l}0.244 \\
(0.55)\end{array}$ & $\begin{array}{l}0.325 \\
(0.73)\end{array}$ \\
\hline Mixed_Institutional & $\begin{array}{l}-0.239 \\
(-0.61)\end{array}$ & $\begin{array}{c}-0.0221 \\
(-0.05)\end{array}$ & $\begin{array}{l}-0.525 \\
(-1.44)\end{array}$ & $\begin{array}{l}-0.520 \\
(-1.25)\end{array}$ \\
\hline LowLoss & $\begin{array}{l}-0.230 \\
(-0.67)\end{array}$ & & & \\
\hline LowLoss_NoPayment & & $\begin{array}{l}-0.547^{c} \\
(-1.55)\end{array}$ & & \\
\hline LowLoss_Payment & & $\begin{array}{l}0.314 \\
(0.71)\end{array}$ & & \\
\hline LowLoss_NonInst & & & $\begin{array}{l}-0.618^{\mathrm{a}} \\
(-1.12)\end{array}$ & \\
\hline LowLoss_Inst & & & $\begin{array}{l}0.504 \\
(1.16)\end{array}$ & \\
\hline LowLoss_NonInst_NoPayment & & & & $\begin{array}{c}-1.114^{* \mathrm{c}} \\
(-2.16)\end{array}$ \\
\hline LowLoss_NonInst_Payment & & & & $\begin{array}{l}0.334 \\
(0.46)\end{array}$ \\
\hline LowLoss_Inst_NoPayment & & & & $\begin{array}{l}0.359 \\
(0.70)\end{array}$ \\
\hline LowLoss_Inst_Payment & & & & $\begin{array}{l}1.141^{\mathrm{b}} \\
(1.37)\end{array}$ \\
\hline Public_Pension & $\begin{array}{l}-0.651 \\
(-1.11)\end{array}$ & $\begin{array}{l}-0.598 \\
(-1.01)\end{array}$ & $\begin{array}{l}-0.406 \\
(-0.67)\end{array}$ & $\begin{array}{l}-0.321 \\
(-0.56)\end{array}$ \\
\hline Labor_Union & $\begin{array}{l}-1.043^{*} \\
(-2.22)\end{array}$ & $\begin{array}{c}-0.952^{+b} \\
(-1.82)\end{array}$ & $\begin{array}{c}-1.447^{* * b} \\
(-2.85)\end{array}$ & $\begin{array}{c}-1.529^{* \mathrm{c}} \\
(-2.58)\end{array}$ \\
\hline Freq_Non-Institutional_Movant_LP & $\begin{array}{c}-3.282^{* * \mathrm{~b}} \\
(-4.53)\end{array}$ & $\begin{array}{c}-2.961^{* * \mathrm{c}} \\
(-4.13)\end{array}$ & $\begin{array}{c}-3.285^{* * c} \\
(-4.09)\end{array}$ & $\begin{array}{c}-3.168^{* * c} \\
(-4.37)\end{array}$ \\
\hline Freq_Institutional_Movant_LP & $\begin{array}{l}0.413 \\
(1.20)\end{array}$ & $\begin{array}{l}0.216 \\
(0.60)\end{array}$ & $\begin{array}{l}0.294 \\
(0.83)\end{array}$ & $\begin{array}{l}0.0580 \\
(0.14)\end{array}$ \\
\hline Top_Attorney50 & $\begin{array}{l}0.158 \\
(0.52)\end{array}$ & $\begin{array}{l}0.207 \\
(0.72)\end{array}$ & $\begin{array}{l}0.107 \\
(0.35)\end{array}$ & $\begin{array}{l}0.215 \\
(0.71)\end{array}$ \\
\hline Section 11 & $\begin{array}{l}0.840^{*} \\
(2.12)\end{array}$ & $\begin{array}{c}0.805^{* a} \\
(2.19)\end{array}$ & $\begin{array}{l}0.610 \\
(1.62)\end{array}$ & $\begin{array}{l}0.407 \\
(1.14)\end{array}$ \\
\hline
\end{tabular}




\begin{tabular}{|c|c|c|c|c|}
\hline Section 14 & $\begin{array}{l}1.318^{+} \\
(2.01)\end{array}$ & $\begin{array}{l}1.545^{* a} \\
(2.41)\end{array}$ & $\begin{array}{l}1.051 \\
(1.63)\end{array}$ & $\begin{array}{l}1.151^{+} \\
(1.97)\end{array}$ \\
\hline Restatement & $\begin{array}{c}0.530 \\
(1.69)\end{array}$ & $\begin{array}{l}0.412^{\mathrm{a}} \\
(1.42)\end{array}$ & $\begin{array}{c}0.711^{* \mathrm{~b}} \\
(2.24)\end{array}$ & $\begin{array}{l}0.514^{\mathrm{b}} \\
(1.55)\end{array}$ \\
\hline Gov_Investigation & $\begin{array}{l}0.103 \\
(0.43)\end{array}$ & $\begin{array}{l}0.114 \\
(0.40)\end{array}$ & $\begin{array}{c}-0.0693 \\
(-0.27)\end{array}$ & $\begin{array}{c}-0.0740 \\
(-0.23)\end{array}$ \\
\hline Officer_Terminated & $\begin{array}{l}-0.101 \\
(-0.39)\end{array}$ & $\begin{array}{c}0.0300 \\
(0.11)\end{array}$ & $\begin{array}{l}-0.163 \\
(-0.62)\end{array}$ & $\begin{array}{c}0.00531 \\
(0.02)\end{array}$ \\
\hline Auditor_Terminated & $\begin{array}{l}-0.664 \\
(-1.10)\end{array}$ & $\begin{array}{l}-0.408 \\
(-0.87)\end{array}$ & $\begin{array}{l}-0.877 \\
(-1.49)\end{array}$ & $\begin{array}{c}-1.042^{+b} \\
(-1.86)\end{array}$ \\
\hline Insider Trading Claim & $\begin{array}{c}0.953^{* * b} \\
(3.02)\end{array}$ & $\begin{array}{c}0.790^{* \mathrm{c}} \\
(2.58)\end{array}$ & $\begin{array}{c}0.889^{* * \mathrm{c}} \\
(3.01)\end{array}$ & $\begin{array}{c}0.697^{* \mathrm{c}} \\
(2.63)\end{array}$ \\
\hline $\ln$ (Market Capitalization) & $\begin{array}{l}0.133 \\
(1.39)\end{array}$ & $\begin{array}{c}0.179^{+c} \\
(1.78)\end{array}$ & $\begin{array}{c}0.173^{+b} \\
(1.72)\end{array}$ & $\begin{array}{c}0.203^{+c} \\
(1.92)\end{array}$ \\
\hline Minimum Return & $\begin{array}{l}1.473 \\
(1.26)\end{array}$ & $\begin{array}{l}1.341 \\
(1.10)\end{array}$ & $\begin{array}{l}0.724 \\
(0.63)\end{array}$ & $\begin{array}{l}0.741 \\
(0.68)\end{array}$ \\
\hline Turnover & $\begin{array}{c}0.00438 \\
(0.01)\end{array}$ & $\begin{array}{l}-0.540 \\
(-0.68)\end{array}$ & $\begin{array}{l}-0.433 \\
(-0.52)\end{array}$ & $\begin{array}{l}-0.797 \\
(-0.96)\end{array}$ \\
\hline High_Tech & $\begin{array}{c}-0.723^{*} \\
(-2.24)\end{array}$ & $\begin{array}{c}-0.604^{+b} \\
(-1.92)\end{array}$ & $\begin{array}{c}-0.678^{+a} \\
(-2.02)\end{array}$ & $\begin{array}{c}-0.658^{* \mathrm{c}} \\
(-2.06)\end{array}$ \\
\hline Independent Board & $\begin{array}{l}-0.407 \\
(-0.57)\end{array}$ & $\begin{array}{l}-0.713 \\
(-1.04)\end{array}$ & $\begin{array}{l}-0.512 \\
(-0.79)\end{array}$ & $\begin{array}{l}-0.784 \\
(-1.26)\end{array}$ \\
\hline Outside Chair & $\begin{array}{l}0.233 \\
(0.78)\end{array}$ & $\begin{array}{l}0.340 \\
(1.22)\end{array}$ & $\begin{array}{l}0.434 \\
(1.50)\end{array}$ & $\begin{array}{c}0.608^{* \mathrm{~b}} \\
(2.22)\end{array}$ \\
\hline Other Boards & $\begin{array}{c}-0.00204 \\
(-0.01)\end{array}$ & $\begin{array}{c}0.00135 \\
(0.01)\end{array}$ & $\begin{array}{c}0.00775 \\
(0.05)\end{array}$ & $\begin{array}{c}-0.0301 \\
(-0.22)\end{array}$ \\
\hline Constant & $\begin{array}{c}7.014^{* * \mathrm{~b}} \\
(9.32) \\
\end{array}$ & $\begin{array}{c}7.328^{* *_{\mathrm{c}}} \\
(8.33) \\
\end{array}$ & $\begin{array}{c}7.207^{* * \mathrm{~b}} \\
(9.50) \\
\end{array}$ & $\begin{array}{c}7.653^{* * \mathrm{c}} \\
(8.28) \\
\end{array}$ \\
\hline $\begin{array}{l}N \\
R^{2}\end{array}$ & $\begin{array}{c}65 \\
0.542\end{array}$ & $\begin{array}{c}65 \\
0.599\end{array}$ & $\begin{array}{c}65 \\
0.570\end{array}$ & $\begin{array}{c}65 \\
0.641\end{array}$ \\
\hline \multicolumn{5}{|c|}{$\begin{array}{l}\text { t } p<0.10,{ }^{*} p<0.05,{ }^{* *} p<0.01 \text {. The dependent variable is } \ln (1+\text { Hours) where Hours is the number of attorney } \\
\text { hours worked as reported in the motion for attorney fees during settlement. The t-statistics (in parentheses) are } \\
\text { calculated using robust standard errors. Unreported, the models include indicator variables for the five federal } \\
\text { circuit courts with the most number of securities class action filings in the dataset (the Second, Third, Fifth, Ninth } \\
\text { and Eleventh Circuits). } \\
\text { a } p<0.10,{ }^{b} p<0.05,{ }^{c} p<0.01 \text { correspond to significance levels for unreported second-stage of a two-stage } \\
\text { Heckman model estimated in STATA. The Heckman first-stage uses settlement }(=1) \text { versus non-settlement }(=0) \text { as } \\
\text { the dependent variable with the number of securities class actions filed in the federal district court as the instrument }\end{array}$} \\
\hline
\end{tabular}


Table 9: Lead Plaintiff Selection Process and Attorney Hours

\begin{tabular}{|c|c|c|c|}
\hline & Model 1 & Model 2 & Model 3 \\
\hline Many_Lead_Plaintiff & $\begin{array}{l}0.0430 \\
(0.17)\end{array}$ & $\begin{array}{l}0.0587 \\
(0.23)\end{array}$ & $\begin{array}{l}0.0210 \\
(0.08)\end{array}$ \\
\hline All_Institutional & $\begin{array}{l}0.296 \\
(1.04)\end{array}$ & $\begin{array}{l}0.269 \\
(1.00)\end{array}$ & $\begin{array}{l}0.0783 \\
(0.26)\end{array}$ \\
\hline Mixed_Institutional & $\begin{array}{l}0.181 \\
(0.61)\end{array}$ & $\begin{array}{l}0.105 \\
(0.37)\end{array}$ & $\begin{array}{r}-0.0507 \\
(-0.18)\end{array}$ \\
\hline Number_Separate_Motions & $\begin{array}{c}0.237^{* \mathrm{c}} \\
(2.35)\end{array}$ & $\begin{array}{c}0.126^{* b} \\
(2.02)\end{array}$ & $\begin{array}{c}0.150^{*}{ }^{*} \\
(2.45)\end{array}$ \\
\hline Number_Withdraw & $\begin{array}{l}-0.195^{\mathrm{b}} \\
(-1.45)\end{array}$ & & \\
\hline Group_Competition & & $\begin{array}{c}1.021^{* b} \\
(2.64)\end{array}$ & \\
\hline Group_No_Competition & & $\begin{array}{l}0.349 \\
(1.16)\end{array}$ & \\
\hline Group_Non-Institution & & & $\begin{array}{l}-0.193 \\
(-0.44)\end{array}$ \\
\hline Group_Institution & & & $\begin{array}{c}1.127^{* * \mathrm{~b}} \\
(2.89)\end{array}$ \\
\hline Top_Attorney50 & $\begin{array}{r}-0.0995 \\
(-0.45)\end{array}$ & $\begin{array}{c}-0.0974 \\
(-0.40)\end{array}$ & $\begin{array}{l}-0.00456 \\
(-0.02)\end{array}$ \\
\hline Constant & $\begin{array}{c}6.571^{* * \mathrm{c}} \\
(9.21) \\
\end{array}$ & $\begin{array}{c}6.458^{* *_{\mathrm{c}}} \\
(8.40) \\
\end{array}$ & $\begin{array}{c}6.781^{* *_{\mathrm{c}}} \\
(9.01) \\
\end{array}$ \\
\hline $\begin{array}{l} \\
R^{2}\end{array}$ & $\begin{array}{c}80 \\
0.471\end{array}$ & $\begin{array}{c}80 \\
0.473\end{array}$ & $\begin{array}{c}80 \\
0.498\end{array}$ \\
\hline \multicolumn{4}{|c|}{$\begin{array}{l}{ }^{+} p<0.10,{ }^{*} p<0.05,{ }^{* *} p<0.01 \text {. The dependent variable is } \ln (1+\text { Hours) where Hours is the number of attorney } \\
\text { hours worked as reported in the motion for attorney fees during settlement. The t-statistics (in parentheses) are } \\
\text { calculated using robust standard errors. Unreported, all models include the Case Strength and Corporate } \\
\text { Governance control variables. Unreported, the models include indicator variables for the five federal circuit courts } \\
\text { the most number of securities class action filings in the dataset (the Second, Third, Fifth, Ninth and Eleventh } \\
\text { Circuits). } \\
\text { a } p<0.10,{ }^{\mathrm{b}} p<0.05,{ }^{\mathrm{c}} p<0.01 \text { correspond to significance levels for unreported second-stage of a two-stage } \\
\text { Heckman model estimated in STATA. The Heckman first-stage uses settlement }(=1) \text { versus non-settlement }(=0) \text { as } \\
\text { the dependent variable with the number of securities class actions filed in the federal district court as the instrument }\end{array}$} \\
\hline
\end{tabular}


Table 10: Lead Plaintiff Composition and the Requested Attorney Fee

\begin{tabular}{|c|c|c|c|c|}
\hline & Model 1 & Model 2 & Model 3 & Model 4 \\
\hline Many_Lead_Plaintiff & $\begin{array}{c}-0.0458 \\
(-0.77)\end{array}$ & $\begin{array}{c}-0.0561 \\
(-0.92)\end{array}$ & $\begin{array}{c}-0.0639 \\
(-1.16)\end{array}$ & $\begin{array}{c}-0.0620 \\
(-1.18)\end{array}$ \\
\hline All_Institutional & $\begin{array}{c}-0.00171 \\
(-0.02)\end{array}$ & $\begin{array}{c}-0.0369 \\
(-0.34)\end{array}$ & $\begin{array}{c}-0.0752 \\
(-0.61)\end{array}$ & $\begin{array}{c}-0.0821 \\
(-0.61)\end{array}$ \\
\hline Mixed_Institutional & $\begin{array}{l}0.0832 \\
(1.24)\end{array}$ & $\begin{array}{l}0.0679 \\
(0.97)\end{array}$ & $\begin{array}{l}0.0142 \\
(0.18)\end{array}$ & $\begin{array}{l}0.0235 \\
(0.30)\end{array}$ \\
\hline LowLoss & $\begin{array}{c}0.100^{+b} \\
(1.71)\end{array}$ & & & \\
\hline LowLoss_NoPayment & & $\begin{array}{l}0.128^{* b} \\
(2.09)\end{array}$ & & \\
\hline LowLoss_Payment & & $\begin{array}{c}0.0523 \\
(0.64)\end{array}$ & & \\
\hline LowLoss_NonInst & & & $\begin{array}{c}-0.0258 \\
(-0.34)\end{array}$ & \\
\hline LowLoss_Inst & & & $\begin{array}{l}0.0772 \\
(0.83)\end{array}$ & \\
\hline LowLoss_NonInst_NoPayment & & & & $\begin{array}{c}0.0381 \\
(0.43)\end{array}$ \\
\hline LowLoss_NonInst_Payment & & & & $\begin{array}{l}-0.113 \\
(-1.22)\end{array}$ \\
\hline LowLoss_Inst_NoPayment & & & & $\begin{array}{c}0.0766 \\
(0.75)\end{array}$ \\
\hline LowLoss_Inst_Payment & & & & $\begin{array}{l}0.153 \\
(1.19)\end{array}$ \\
\hline Public_Pension & $\begin{array}{l}-0.158 \\
(-1.12)\end{array}$ & $\begin{array}{l}-0.142 \\
(-1.01)\end{array}$ & $\begin{array}{l}-0.159 \\
(-1.10)\end{array}$ & $\begin{array}{l}-0.140 \\
(-0.97)\end{array}$ \\
\hline Labor_Union & $\begin{array}{c}-0.0703 \\
(-0.66)\end{array}$ & $\begin{array}{c}-0.0518 \\
(-0.47)\end{array}$ & $\begin{array}{c}-0.0794 \\
(-0.70)\end{array}$ & $\begin{array}{c}-0.0644 \\
(-0.54)\end{array}$ \\
\hline Freq_Non-Institutional_Movant_LP & $\begin{array}{l}0.0175 \\
(0.13)\end{array}$ & $\begin{array}{l}0.0125 \\
(0.09)\end{array}$ & $\begin{array}{l}0.0516 \\
(0.38)\end{array}$ & $\begin{array}{l}0.104 \\
(0.81)\end{array}$ \\
\hline Freq_Institutional_Movant_LP & $\begin{array}{c}-0.142^{+a} \\
(-1.91)\end{array}$ & $\begin{array}{c}-0.139^{+} \\
(-1.86)\end{array}$ & $\begin{array}{c}-0.159^{+b} \\
(-1.87)\end{array}$ & $\begin{array}{c}-0.160^{+b} \\
(-1.97)\end{array}$ \\
\hline $\ln ($ Set Amount $)$ & $\begin{array}{c}-0.0205 \\
(-0.66)\end{array}$ & $\begin{array}{c}-0.00813 \\
(-0.24)\end{array}$ & $\begin{array}{c}-0.0191 \\
(-0.62)\end{array}$ & $\begin{array}{c}-0.0103 \\
(-0.30)\end{array}$ \\
\hline Top_Attorney50 & $\begin{array}{c}-0.0304 \\
(-0.62)\end{array}$ & $\begin{array}{c}-0.0410 \\
(-0.80)\end{array}$ & $\begin{array}{c}-0.0168 \\
(-0.34)\end{array}$ & $\begin{array}{c}-0.0392 \\
(-0.74)\end{array}$ \\
\hline Constant & $\begin{array}{c}-0.865^{* * b} \\
(-4.39) \\
\end{array}$ & $\begin{array}{c}-0.920^{* * b} \\
(-4.76)\end{array}$ & $\begin{array}{c}-0.830^{* * b} \\
(-4.17)\end{array}$ & $\begin{array}{c}-0.872^{* *} \\
(-4.61)\end{array}$ \\
\hline $\begin{array}{l}N \\
R^{2}\end{array}$ & $\begin{array}{c}85 \\
0.467 \\
\end{array}$ & $\begin{array}{c}85 \\
0.476 \\
\end{array}$ & $\begin{array}{c}85 \\
0.443 \\
\end{array}$ & $\begin{array}{c}85 \\
0.460 \\
\end{array}$ \\
\hline
\end{tabular}


${ }^{+} p<0.10,{ }^{*} p<0.05,{ }^{* *} p<0.01$. The dependent variable is $\ln$ (Atty_Fee/1-Atty_Fee) where Atty_Fee is the requested attorney fee negotiated between lead plaintiff and lead counsel measured as a percentage of the settlement amount. The t-statistics (in parentheses) are calculated using robust standard errors. Unreported, all models include the Case Strength and Corporate Governance control variables. Unreported, the models include indicator variables for the five federal circuit courts the most number of securities class action filings in the dataset (the Second, Third, Fifth, Ninth and Eleventh Circuits).

${ }^{\mathrm{a}} p<0.10,{ }^{\mathrm{b}} p<0.05,{ }^{\mathrm{c}} p<0.01$ correspond to significance levels for unreported second-stage of a two-stage Heckman model estimated in STATA. The Heckman first-stage uses settlement $(=1)$ versus non-settlement $(=0)$ as the dependent variable with the number of securities class actions filed in the federal district court as the instrument. 
Table 11: Lead Plaintiff Selection Process and the Requested Attorney Fee

\begin{tabular}{|c|c|c|c|}
\hline & Model 1 & Model 2 & Model 3 \\
\hline Many_Lead_Plaintiff & $\begin{array}{l}-0.0305 \\
(-0.51)\end{array}$ & $\begin{array}{l}-0.0236 \\
(-0.42)\end{array}$ & $\begin{array}{c}-0.0389 \\
(-0.66)\end{array}$ \\
\hline All_Institutional & $\begin{array}{c}-0.128^{+b} \\
(-1.97)\end{array}$ & $\begin{array}{c}-0.131^{* b} \\
(-2.09)\end{array}$ & $\begin{array}{c}-0.109^{+b} \\
(-1.71)\end{array}$ \\
\hline Mixed_Institutional & $\begin{array}{c}0.0144 \\
(0.24)\end{array}$ & $\begin{array}{c}0.0329 \\
(0.52)\end{array}$ & $\begin{array}{c}0.0844 \\
(1.29)\end{array}$ \\
\hline Number_Separate_Motions & $\begin{array}{c}-0.0251^{\mathrm{b}} \\
(-1.63)\end{array}$ & $\begin{array}{c}-0.0142 \\
(-1.34)\end{array}$ & $\begin{array}{c}-0.0189^{+a} \\
(-1.81)\end{array}$ \\
\hline Number_Withdraw & $\begin{array}{l}0.0187 \\
(0.83)\end{array}$ & & \\
\hline Group_Competition & & $\begin{array}{l}-0.193^{b} \\
(-1.33)\end{array}$ & \\
\hline Group_No_Competition & & $\begin{array}{c}-0.0727 \\
(-0.60)\end{array}$ & \\
\hline Group_Non-Institution & & & $\begin{array}{c}-0.0109 \\
(-0.07)\end{array}$ \\
\hline Group_Institution & & & $\begin{array}{l}-0.242^{* \mathrm{c}} \\
(-2.14)\end{array}$ \\
\hline $\ln ($ Set Amount) & $\begin{array}{c}0.00219 \\
(0.08)\end{array}$ & $\begin{array}{c}0.00202 \\
(0.07)\end{array}$ & $\begin{array}{c}0.00985 \\
(0.37)\end{array}$ \\
\hline Top_Attorney50 & $\begin{array}{c}-0.0445 \\
(-0.80)\end{array}$ & $\begin{array}{c}-0.0402 \\
(-0.78)\end{array}$ & $\begin{array}{c}-0.0592 \\
(-1.17)\end{array}$ \\
\hline Constant & $\begin{array}{c}-0.708^{* *_{c}} \\
(-4.00) \\
\end{array}$ & $\begin{array}{c}-0.640^{* * b} \\
(-3.15) \\
\end{array}$ & $\begin{array}{c}-0.632^{* * b} \\
(-3.15)\end{array}$ \\
\hline $\begin{array}{l}N \\
R^{2}\end{array}$ & $\begin{array}{c}114 \\
0.319\end{array}$ & $\begin{array}{c}114 \\
0.344\end{array}$ & $\begin{array}{c}114 \\
0.359\end{array}$ \\
\hline
\end{tabular}

${ }^{+} p<0.10,{ }^{*} p<0.05,{ }^{* *} p<0.01$. The dependent variable is $\ln$ (Atty_Fee/1-Atty_Fee) where Atty_Fee is the requested attorney fee negotiated between lead plaintiff and lead counsel measured as a percentage of the settlement amount. The t-statistics (in parentheses) are calculated using robust standard errors. Unreported, all models include the Case Strength and Corporate Governance control variables. Unreported, the models include indicator variables for the five federal circuit courts the most number of securities class action filings in the dataset (the Second, Third, Fifth, Ninth and Eleventh Circuits).

${ }^{\mathrm{a}} p<0.10,{ }^{\mathrm{b}} p<0.05,{ }^{\mathrm{c}} p<0.01$ correspond to significance levels for unreported second-stage of a two-stage Heckman model estimated in STATA. The Heckman first-stage uses settlement $(=1)$ versus non-settlement $(=0)$ as the dependent variable with the number of securities class actions filed in the federal district court as the instrument. 
Many_Lead_Plaintiff

All_Institutional

Mixed_Institutional

LowLoss

LowLoss_Non-Inst

LowLoss_Inst

LowLoss_NoPayment

LowLoss_Payment

LowLoss_Non-Inst_NoPayment

LowLoss_Inst_NoPayment
Indicator variable equal to 1 if the appointed lead plaintiff in a particular class action consists of more than three separate members and 0 otherwise. Note that individual members of the same family are all treated as only one member.

Indicator variable equal to 1 if the appointed lead plaintiff in a particular class action consists of only institutional investor members and 0 otherwise.

Indicator variable equal to 1 if the appointed lead plaintiff in a particular class action consists of both institutional investor and non-institutional investor members and 0 otherwise.

Indicator variable equal to 1 if the claimed losses of the appointed lead plaintiff is less than or equal to the median for the group of all lead plaintiffs and 0 otherwise.

Indicator variable equal to 1 if the appointed lead plaintiff consists of only non-institutional investors and the claimed losses of the appointed lead plaintiff is less than or equal to the median for non-institutional investor-only lead plaintiffs and 0 otherwise.

Indicator variable equal to 1 if the appointed lead plaintiff consists of at least one institutional investor and the claimed losses of the appointed lead plaintiff is less than or equal to the median for lead plaintiffs with at least one institutional investor and 0 otherwise.

Indicator variable equal to 1 if (a) the claimed losses of the appointed lead plaintiff is less than or equal to the median for the group of all lead plaintiffs and (b) the lead plaintiff did not negotiate for the lead counsel to submit an application to the court for a separate lead plaintiff payment and 0 otherwise.

Indicator variable equal to 1 if (a) the claimed losses of the appointed lead plaintiff is less than or equal to the median for the group of all lead plaintiffs and (b) the lead plaintiff negotiated for the lead counsel to submit an application to the court for a separate lead plaintiff payment and 0 otherwise.

Indicator variable equal to 1 if the appointed lead plaintiff consists of only non-institutional investors and (a) the claimed losses of the appointed lead plaintiff is less than or equal to the median for noninstitutional investor-only lead plaintiffs and (b) the lead plaintiff did not negotiate for the lead counsel to submit an application to the court for a separate lead plaintiff payment and 0 otherwise.

Indicator variable equal to 1 if the appointed lead plaintiff consists of at least one institutional investor and (a) the claimed losses of the appointed lead plaintiff is less than or equal to the median for lead plaintiffs with at least one institutional investor and (b) the lead plaintiff did not negotiate for the lead counsel to submit an application to the court for a separate 
LowLoss_Non-Inst_Payment

LowLoss_Inst_Payment

Public_Pension

Labor_Union

Frequent_Non-Institutional_Movant

Frequent_Institutional_Movant

Freq_Non-Institutional_Movant_LP

Frequent_Institutional_Movant_LP

Group_Competition

Group_No_Competition

Group_Institution

Group_Non-Institution lead plaintiff payment and 0 otherwise.

Indicator variable equal to 1 if the appointed lead plaintiff consists of only non-institutional investors and (a) the claimed losses of the appointed lead plaintiff is less than or equal to the median for noninstitutional investor-only lead plaintiffs and (b) the lead plaintiff negotiated for the lead counsel to submit an application to the court for a separate lead plaintiff payment and 0 otherwise.

Indicator variable equal to 1 if the appointed lead plaintiff consists of at least one institutional investor and (a) the claimed losses of the appointed lead plaintiff is less than or equal to the median for lead plaintiffs with at least one institutional investor and (b) the lead plaintiff negotiated for the lead counsel to submit an application to the court for a separate lead plaintiff payment and 0 otherwise.

Indicator variable equal to 1 if the appointed lead plaintiff consists of at least one public pension fund and 0 otherwise.

Indicator variable equal to 1 if the appointed lead plaintiff consists of at least one labor union pension fund and 0 otherwise.

Indicator variable equal to 1 if a non- institutional investor was a movant to be a lead plaintiff in at least 2 different class and 0 otherwise.

Indicator variable equal to 1 if an institutional investor was a movant to be a lead plaintiff in at least 2 different class and 0 otherwise.

Indicator variable equal to 1 if the appointed lead plaintiff consists of at least one non-institutional investor that was a movant to be a lead plaintiff in at least 2 different class actions and 0 otherwise and 0 otherwise.

Indicator variable equal to 1 if the appointed lead plaintiff consists of at least one institutional investor that was a movant to be a lead plaintiff in at least 2 different class actions and 0 otherwise and 0 otherwise.

Indicator variable equal to 1 if the appointed lead plaintiff consists of members from at least 2 separate competing motions for lead plaintiff and the group is selected despite opposition from other motions for lead plaintiff and 0 otherwise.

Indicator variable equal to 1 if the appointed lead plaintiff consists of members from at least 2 separate competing motions for lead plaintiff and the group is aggregated without competition from other motions for lead plaintiff and 0 otherwise.

Indicator variable equal to 1 if the appointed lead plaintiff consists of members from at least 2 separate competing motions for lead plaintiff and at least one institutional investor is a member of the lead plaintiff and 0 otherwise.

Indicator variable equal to 1 if the appointed lead plaintiff consists of members from at least 2 separate competing motions for lead plaintiff and no institutional investor is a member of the lead plaintiff and 0 otherwise. 
Settlement Amount

Section 11

Section 14

Restatement

Gov_Investigation

Officer_Terminated

Auditor_Terminated

Insider Trading Claim

Market Capitalization

Minimum Return

Turnover

High_Tech

Independent_Board

Outside Chair

Other Boards
Settlement amount in millions of dollars.

Indicator variable equal to 1 if the complaint for a particular class actions alleged a Section 11 of the Securities Act of 1933 violation and 0 otherwise.

Indicator variable equal to 1 if the complaint for a particular class actions alleged a Section 14(a) of the Securities Act of 1934 violation and 0 otherwise.

Indicator variable equal to 1 if the complaint indicated that the company announced a restatement covering at least part of the class period and 0 otherwise.

Indicator variable equal to 1 if the complaint indicated the presence of a SEC or other governmental investigation or enforcement action relating to the fraud at issue and 0 otherwise.

Indicator variable equal to 1 if the complaint indicated that a top officer of the defendant company resigned or was terminated during the class period and 0 otherwise.

Indicator variable equal to 1 if the complaint indicated that the auditor resigned or was terminated during the class period and 0 otherwise.

Indicator variable equal to 1 if the complaint alleged insider trading and 0 otherwise.

Market value of a company's common equity (in \$ millions) at the end of the fiscal year preceding the beginning of the class period

Minimum one-day return during the class period plus one day after the end of the class period

$1-(1-\text { Turn })^{\mathrm{X}}$, where Turn is average daily trading volume divided by the number of shares outstanding, and $\mathrm{X}$ is the number of trading days during the class period

Indicator variable equal to 1 if the firm is in SIC codes $3570-3577$ or 7370-7379 and 0 otherwise

The percentage of independent directors (outside directors with no consulting, familial, prior employment, or other financial relationship with an insider) on the firm's board

Indicator variable equal to 1 if a non-executive chair sits on the board of directors and 0 otherwise

Mean number of external directorships of public companies held by outside directors

The governance variables are obtained from the last available proxy statement preceding the beginning of the class period, if available; if not, the first available proxy after the beginning of the class period was used. 


\section{Appendix B: Lead Plaintiff Motion Examples}

\section{Example 1: Intermune}

Motions for Lead Plaintiff

\begin{tabular}{lcll}
\hline Movant & $\begin{array}{c}\text { Claimed } \\
\text { Loss }\end{array}$ & Proposed Lead Counsel & Liaison Counsel \\
\hline Herthel Family & 15,078 & Schiffrin \& Barroway LLP & Green \& Jigarjian LLP \\
Lance A. Johnson & 40,000 & $\begin{array}{l}\text { Goodkind Labaton Rudoff } \\
\text { \& Sucharow LLP }\end{array}$ & \\
Gerald Fraschilla and Darlene & 57,735 & $\begin{array}{l}\text { Milberg Weiss Bershad } \\
\text { Fynes \& Lerach LLP }\end{array}$ & \\
Pyotyr Lipavsky & & $\begin{array}{l}\text { Cauley Geller Bowman } \\
\text { Coates \& Rudman LLP }\end{array}$ & Glancy \& Binkow LLP \\
& 5,175 & & \\
\hline
\end{tabular}

\section{Motion Outcome}

\begin{tabular}{llll}
\hline Movant & Outcome & Selected Lead Counsel & Selected Lead Plaintiffs \\
\hline Herthel Family & Withdrew & & \\
Lance A. Johnson & Granted & $\begin{array}{l}\text { Goodkind Labaton Rudoff } \\
\text { \& Sucharow LLP }\end{array}$ & Lance A. Johnson \\
Gerald Fraschilla and Darlene & Withdrew & \\
Fraschilla & Withdrew & \\
Pyotyr Lipavsky & & \\
\end{tabular}


Example 2: Spear \& Jackson, Inc.

Motions for Lead Plaintiff

\begin{tabular}{|c|c|c|c|}
\hline Movant & $\begin{array}{l}\text { Claimed } \\
\text { Loss }\end{array}$ & Proposed Lead Counsel & Liaison Counsel \\
\hline Charles J. Rozenas & 178,070 & Geller Rudman, PLLC & \\
\hline $\begin{array}{l}\text { Faye Morgenstern (Trustee of } \\
\text { Morningstar Trust), Marvin } \\
\text { Friedman, Allen J. Sakes, Judd } \\
\text { Morgenstern, William L. Denam Jr. }\end{array}$ & 226,033 & $\begin{array}{l}\text { Milberg Weiss Bershad \& } \\
\text { Schulman LLP; Schiffrin \& } \\
\text { Barroway LLP }\end{array}$ & \\
\hline $\begin{array}{l}\text { J. Claude Wheeler Jr., Dennis } \\
\text { Holland, Daniel Sciro }\end{array}$ & 182,000 & $\mathrm{Scott}+\mathrm{Scott}$ LLC & \\
\hline $\begin{array}{l}\text { First Mirage Inc., Profit Concepts } \\
\text { Ltd., Generation Capital Assoc.; } \\
\text { American Merchant Press Inc. }\end{array}$ & $1,380,431$ & $\begin{array}{l}\text { Law Offices of Bernard M. } \\
\text { Gross }\end{array}$ & Vianale and Vianale \\
\hline
\end{tabular}

\section{Motion Outcome}

\begin{tabular}{|c|c|c|c|}
\hline Movant & Outcome & Selected Lead Counsel & Selected Lead Plaintiffs \\
\hline Charles J. Rozenas & Granted & $\begin{array}{l}\text { Lerach Coughlin Stoia } \\
\text { Geller Rudman \& Robbins } \\
\text { LLP* }\end{array}$ & Charles J. Rozenas \\
\hline $\begin{array}{l}\text { Faye Morgenstern (Trustee of } \\
\text { Morningstar Trust), Marvin } \\
\text { Friedman, Allen J. Sakes, Judd } \\
\text { Morgenstern, William L. Denam Jr. }\end{array}$ & Granted & Schiffrin \& Barroway LLP & Faye Morgenstern \\
\hline $\begin{array}{l}\text { J. Claude Wheeler Jr., Dennis } \\
\text { Holland, Daniel Sciro }\end{array}$ & Rejected & & \\
\hline $\begin{array}{l}\text { First Mirage Inc., Profit Concepts } \\
\text { Ltd., Generation Capital Assoc.; } \\
\text { American Merchant Press Inc. }\end{array}$ & Granted & $\begin{array}{l}\text { Law Offices of Bernard M. } \\
\text { Gross PC }\end{array}$ & $\begin{array}{l}\text { First Mirage Inc., Profit } \\
\text { Concepts Ltd., Generation } \\
\text { Capital Assoc.; American } \\
\text { Merchant Press Inc. }\end{array}$ \\
\hline
\end{tabular}




\section{Appendix C: Frequent Lead Plaintiff Movants}

\section{Frequent Institutional Movants}

\begin{tabular}{|c|c|c|c|c|}
\hline Frequent Movant & Most Frequent Attorney & $\begin{array}{l}\text { Number } \\
\text { of Motions }\end{array}$ & $\begin{array}{l}\text { Granted } \\
\text { Fraction }\end{array}$ & $\begin{array}{l}\text { Withdraw } \\
\text { Fraction }\end{array}$ \\
\hline Louisiana State & $\begin{array}{l}\text { Bernstein Litowitz Berger \& Grosman, } \\
\text { LLP }\end{array}$ & 18 & 0.556 & 0.056 \\
\hline $\begin{array}{l}\text { Central Laborers' Pension } \\
\text { Fund }\end{array}$ & $\begin{array}{l}\text { Milberg Weiss Bershad Hynes \& Lerach } \\
\text { LLP / Lerach Coughlin Stoia Geller } \\
\text { Rudman \& Robbins LLP / Milberg } \\
\text { Weiss Bershad \& Schulman LLP }\end{array}$ & 14 & 0.786 & 0.214 \\
\hline $\begin{array}{l}\text { Alaska Electrical Pension } \\
\text { Fund }\end{array}$ & $\begin{array}{l}\text { Milberg Weiss Bershad Hynes \& Lerach } \\
\text { LLP / Lerach Coughlin Stoia Geller } \\
\text { Rudman \& Robbins LLP }\end{array}$ & 12 & 0.667 & 0.250 \\
\hline $\begin{array}{l}\text { Massachusetts State } \\
\text { Carpenters Pension Fund }\end{array}$ & $\begin{array}{l}\text { Milberg Weiss Bershad Hynes \& Lerach } \\
\text { LLP / Lerach Coughlin Stoia Geller } \\
\text { Rudman \& Robbins LLP }\end{array}$ & 12 & 0.417 & 0.000 \\
\hline $\begin{array}{l}\text { Massachusetts State } \\
\text { Guaranteed Annuity Fund }\end{array}$ & $\begin{array}{l}\text { Milberg Weiss Bershad Hynes \& Lerach } \\
\text { LLP / Lerach Coughlin Stoia Geller } \\
\text { Rudman \& Robbins LLP }\end{array}$ & 12 & 0.250 & 0.000 \\
\hline City of Dearborn Heights & $\begin{array}{l}\text { Milberg Weiss Bershad Hynes \& Lerach } \\
\text { LLP / Lerach Coughlin Stoia Geller } \\
\text { Rudman \& Robbins LLP }\end{array}$ & 10 & 0.900 & 0.100 \\
\hline City of Sterling Heights & $\begin{array}{l}\text { Milberg Weiss Bershad Hynes \& Lerach } \\
\text { LLP / Lerach Coughlin Stoia Geller } \\
\text { Rudman \& Robbins LLP }\end{array}$ & 9 & 0.889 & 0.111 \\
\hline $\begin{array}{l}\text { NECA-IBEW Pension } \\
\text { Fund (the Decatur Plan) }\end{array}$ & $\begin{array}{l}\text { Lerach Coughlin Stoia Geller Rudman \& } \\
\text { Robbins LLP }\end{array}$ & 9 & 0.667 & 0.111 \\
\hline $\begin{array}{l}\text { New Jersey Building } \\
\text { Laborers Pension Fund }\end{array}$ & $\begin{array}{l}\text { Milberg Weiss Bershad \& Schulman } \\
\text { LLP }\end{array}$ & 7 & 0.000 & 0.429 \\
\hline $\begin{array}{l}\text { Central States, Southeast } \\
\text { and Southwest Areas } \\
\text { Pension Fund }\end{array}$ & $\begin{array}{l}\text { Milberg Weiss Bershad Hynes \& Lerach } \\
\text { LLP / Lerach Coughlin Stoia Geller } \\
\text { Rudman \& Robbins LLP }\end{array}$ & 6 & 0.333 & 0.000 \\
\hline City of Pontiac & $\begin{array}{l}\text { Lerach Coughlin Stoia Geller Rudman \& } \\
\text { Robbins LLP }\end{array}$ & 6 & 0.667 & 0.000 \\
\hline
\end{tabular}




\begin{tabular}{|c|c|c|c|c|}
\hline City of St. Clair Shores & $\begin{array}{l}\text { Lerach Coughlin Stoia Geller Rudman \& } \\
\text { Robbins LLP }\end{array}$ & 6 & 0.500 & 0.000 \\
\hline $\begin{array}{l}\text { Massachusetts Laborers' } \\
\text { Annuity Fund }\end{array}$ & $\begin{array}{l}\text { Milberg Weiss Bershad Hynes \& Lerach } \\
\text { LLP / Lerach Coughlin Stoia Geller } \\
\text { Rudman \& Robbins LLP }\end{array}$ & 6 & 0.667 & 0.167 \\
\hline $\begin{array}{l}\text { National Elevator Industry } \\
\text { Pension Fund }\end{array}$ & $\begin{array}{l}\text { Lerach Coughlin Stoia Geller Rudman \& } \\
\text { Robbins LLP }\end{array}$ & 6 & 0.500 & 0.167 \\
\hline Oklahoma State & Schiffrin \& Barroway LLP & 6 & 0.167 & 0.167 \\
\hline $\begin{array}{l}\text { Plumbers and Pipefitters } \\
\text { National Pension Fund }\end{array}$ & $\begin{array}{l}\text { Lerach Coughlin Stoia Geller Rudman \& } \\
\text { Robbins LLP }\end{array}$ & 6 & 0.333 & 0.333 \\
\hline $\begin{array}{l}\text { Wayne County Employees' } \\
\text { Retirement System }\end{array}$ & $\begin{array}{l}\text { Lerach Coughlin Stoia Geller Rudman \& } \\
\text { Robbins LLP }\end{array}$ & 6 & 0.667 & 0.167 \\
\hline City of Detroit & Kirby McInerney \& Squire LLP & 5 & 0.200 & 0.200 \\
\hline City of Roseville & $\begin{array}{l}\text { Lerach Coughlin Stoia Geller Rudman \& } \\
\text { Robbins LLP }\end{array}$ & 5 & 0.600 & 0.000 \\
\hline $\begin{array}{l}\text { Greater Pennsylvania } \\
\text { Carpenters Pension Fund }\end{array}$ & $\begin{array}{l}\text { Milberg Weiss Bershad Hynes \& Lerach } \\
\text { LLP / Lerach Coughlin Stoia Geller } \\
\text { Rudman \& Robbins LLP }\end{array}$ & 5 & 0.600 & 0.000 \\
\hline $\begin{array}{l}\text { United Food \& } \\
\text { Commercial Workers } \\
\text { Union Local } 655 \text { AFL-CIO } \\
\text { Food Employers Joint } \\
\text { Pension Plan }\end{array}$ & $\begin{array}{l}\text { Milberg Weiss Bershad Hynes \& Lerach } \\
\text { LLP / Lerach Coughlin Stoia Geller } \\
\text { Rudman \& Robbins LLP / Milberg } \\
\text { Weiss Bershad \& Schulman LLP }\end{array}$ & 4 & 0.750 & 0.000 \\
\hline \multicolumn{5}{|c|}{$\begin{array}{l}\text { Most Frequent Attorney is the attorney firm that is proposed as lead counsel the most number of times for the } \\
\text { frequent movant in question. Milberg Weiss Bershad Hynes \& Lerach LLP split into Lerach Coughlin Stoia Geller } \\
\text { Rudman \& Robbins LLP and Milberg Weiss Bershad \& Schulman LLP in 2004. I treat the use of any of these three } \\
\text { firms equivalent to using the same firm for purposes of determining the Most Frequent Attorney. Granted Fraction } \\
\text { is the fraction of motions where the frequent movant was selected as lead plaintiff. Withdraw Fraction is the } \\
\text { fraction of motions where the frequent movant withdrew its motion for lead plaintiff voluntarily. }\end{array}$} \\
\hline
\end{tabular}


Frequent Non-Institutional Investor Movants

\begin{tabular}{|c|c|c|c|c|}
\hline Frequent Movant & Most Frequent Attorney & $\begin{array}{l}\text { Number } \\
\text { of Motions }\end{array}$ & $\begin{array}{l}\text { Granted } \\
\text { Fraction }\end{array}$ & $\begin{array}{l}\text { Withdraw } \\
\text { Fraction }\end{array}$ \\
\hline Individual Investor A & Stull, Stull \& Brody & 3 & 0.000 & 0.000 \\
\hline Individual Investor B & Schiffrin \& Barroway, LLP & 3 & 0.000 & 0.667 \\
\hline Individual Investor C & $\begin{array}{l}\text { Wolf Haldenstein Adler Freeman \& Herz } \\
\text { LLP }\end{array}$ & 3 & 0.000 & 0.000 \\
\hline Individual Investor D & Milberg Weiss Bershad \& Schulman LLP & 2 & 1.000 & 0.000 \\
\hline Individual Investor E & $\begin{array}{l}\text { Wolf Haldenstein Adler Freeman \& Herz } \\
\text { LLP }\end{array}$ & 2 & 0.500 & 0.000 \\
\hline Individual Investor F & $\begin{array}{l}\text { Lerach Coughlin Stoia Geller Rudman \& } \\
\text { Robbins LLP }\end{array}$ & 2 & 1.000 & 0.000 \\
\hline Individual Investor G & Schiffrin \& Barroway LLP & 2 & 0.500 & 0.500 \\
\hline Individual Investor H & $\begin{array}{l}\text { Wolf Haldenstein Adler Freeman \& Herz } \\
\text { LLP }\end{array}$ & 2 & 0.000 & 0.000 \\
\hline Individual Investor I & Schiffrin \& Barroway LLP & 2 & 0.000 & 1.000 \\
\hline Individual Investor J & Milberg Weiss Bershad \& Schulman LLP & 2 & 0.000 & 0.500 \\
\hline Individual Investor K & Cauley, Geller, Bowman \& Rudman, LLP & 2 & 0.500 & 0.500 \\
\hline Individual Investor L & Milberg Weiss Bershad \& Schulman LLP & 2 & 0.500 & 0.000 \\
\hline Individual Investor M & $\begin{array}{l}\text { Lerach Coughlin Stoia Geller Rudman \& } \\
\text { Robbins LLP }\end{array}$ & 2 & 0.500 & 0.000 \\
\hline Individual Investor N & Wolf Popper LLP & 2 & 0.000 & 1.000 \\
\hline Individual Investor O & $\begin{array}{l}\text { Cauley Geller Bowman Coates \& } \\
\text { Rudman LLP }\end{array}$ & 2 & 0.000 & 0.000 \\
\hline Individual Investor P & Milberg Weiss Bershad \& Schulman LLP & 2 & 0.000 & 0.000 \\
\hline
\end{tabular}




\begin{tabular}{lllll}
\hline Individual Investor Q & Milberg Weiss Bershad \& Schulman LLP & 2 & 0.000 & 0.000 \\
& Milberg Weiss Bershad \& Schulman LLP & 2 & 0.500 & 0.500 \\
Individual Investor R & & & & 0.500 \\
$\begin{array}{l}\text { Non-Institutional Investor } \\
\text { Entity A }\end{array}$ & Schiffrin \& Barroway LLP & 2 & 0.500 & \\
\hline
\end{tabular}

Most Frequent Attorney is the attorney firm that is proposed as lead counsel the most number of times for the frequent movant in question. Granted Fraction is the fraction of motions where the frequent movant was selected as lead plaintiff. Withdraw Fraction is the fraction of motions where the frequent movant withdrew its motion for lead plaintiff voluntarily. 


\section{Appendix D: Frequent Selected Lead Counsel}

\begin{tabular}{lc}
\hline Firms Appointed Lead Counsel 50 or More Times in the Dataset & Number of Cases \\
\hline Lerach Coughlin Stoia Geller Rudman \& Robbins LLP & 121 \\
Schiffrin \& Barroway LLP & 72 \\
Milberg Weiss Bershad \& Schulman LLP & 67 \\
Milberg Weiss Bershad Hynes \& Lerach LLP* & 17
\end{tabular}

\begin{tabular}{lc}
\hline Firms Appointed Lead Counsel 20 to 49 Times in the Dataset & \\
\hline Cauley Geller Bowman \& Rudman LLP & 23 \\
Cohen, Milstein, Hausfeld \& Toll, PLLC & 23 \\
Bernstein Litowitz Berger \& Grossman LLP & 20
\end{tabular}

\footnotetext{
Firms Appointed Lead Counsel 10 to 19 Times in the Dataset

Goodkind Labaton Rudoff \& Sucharow LLP (and Labaton Sucharow \& Rudoff LLP) 16

Glancy Binkow \& Goldberg LLP 15

Murray, Frank \& Sailer LLP

Berger \& Montague P.C.

Schatz \& Nobel, P.C.

Wolf Haldenstein Adler Freeman \& Herz LLP

10

*Milberg Weiss Bershad Hynes \& Lerach LLP split into Lerach Coughlin Stoia Geller Rudman \& Robbins LLP and Milberg Weiss Bershad \& Schulman LLP in 2004. Many of the movants that proposed Milberg Weiss Bershad Hynes \& Lerach LLP initially eventually chose either Lerach Coughlin Stoia Geller Rudman \& Robbins LLP or Milberg Weiss Bershad \& Schulman LLP as the lead counsel. Consequently, the Table also includes Milberg Weiss Bershad Hynes \& Lerach LLP among the attorney firms that were selected 50 or more times even though Milberg Weiss Bershad Hynes \& Lerach LLP was formally selected lead counsel only 17 times in the dataset.
} 